\title{
The State of the National Initiative on Prevention through Design
}
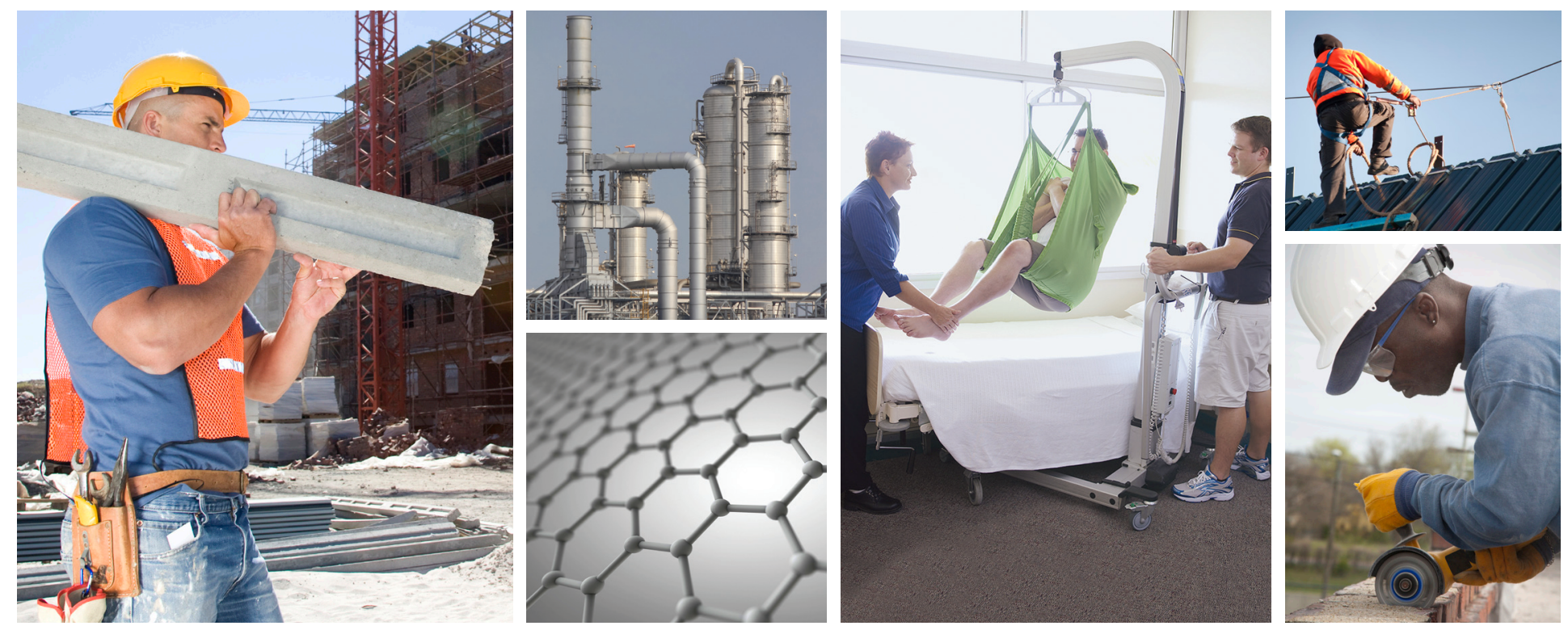

PROGRESS REPORT 2014

DEPARTMENT OF HEALTH AND HUMAN SERVICES Centers for Disease Control and Prevention National Institute for Occupational Safety and Health

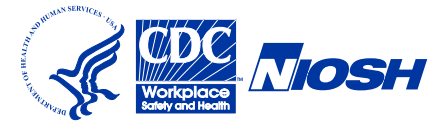




\section{Mission Statement}

The mission of the Prevention through Design National initiative is to prevent occupational injuries, illnesses, and fatalities through the inclusion of prevention considerations in all designs that impact workers. The mission can be achieved by:

- Eliminating hazards and controlling risks to workers to an acceptable level "at the source" or as early as possible in the life cycle of equipment, products, or workplaces.

- Including worker safety and health in design, redesign and retrofit of new and existing work premises, structures, tools, facilities, equipment, machinery, products, substances, work processes and the organization of work.

- Enhancing the work environment through the inclusion of prevention methods in all designs that impact workers and others on the premises. 


\section{Disclaimer}

Mention of any company or product does not constitute endorsement by NIOSH. In addition, citation to websites external to NIOSH do not constitute NIOSH endorsement of the sponsoring organization or their programs or products. Furthermore, NIOSH is not responsible for the content of these websites.

\section{Ordering Information}

This document is in the public domain and may be freely copied or reprinted. To receive NIOSH documents or other information about occupational safety and health topics, contract NIOSH at:

Telephone: 1-800-CDC-INFO (1-800-232-4636)

TTY: 1-888-232-6348

E-mail: cdcinfo@cdc.gov

or visit the NIOSH website at www.cdc.gov/niosh

For a monthly update on news at NIOSH, subscribe to NIOSH eNews by visiting www.cdc.gov/niosh/eNews.

\section{Suggested Citation}

NIOSH [2013]. The state of the national initiative on prevention through design. Cincinnati, OH: U.S. Department of Health and Human Services, Centers for Disease Control and Prevention, National Institute for Occupational Safety and Health, DHHS (NIOSH) Publication No. 2014-123.

DHHS (NIOSH) Publication No. 2014-123

May 2014

SAfer ・ HeAlthier • PEOPle ${ }^{\text {TM }}$ 


\section{Foreword}

Anticipating and designing out hazards in tools, equipment, processes, materials, structures, and the organization of work is the most effective way to prevent occupational injuries, illnesses, and fatalities. In 2007, building on the work of a critical mass of investigators and practitioners, NIOSH partnered with the American Industrial Hygiene Association (AIHA), the American Society of Safety Engineers (ASSE), the Center for Construction Research and Training (CPWR), Kaiser Permanente, Liberty Mutual, the National Safety Council (NSC), the Occupational Safety and Health Administration (OSHA), ORCHSE Strategies, LLC (formerly Mercer, ORC Worldwide ${ }^{\mathrm{TM}}$ ), the Regenstrief Center for Healthcare Engineering, and the Association of Equipment Manufacturers to launch a National Prevention through Design $(\mathrm{PtD})$ initiative.

The initiative involved numerous partnerships with other government agencies, academia, industry, labor, and nongovernmental organizations to make an impact on research, education, policy, and practice related to preventing occupational hazards through design. The initiative was initially framed to span the period of 2007-2014. This report provides an overview of the progress and accomplishments of the PtD initiative. The ultimate goal of the PtD initiative is to prevent or reduce occupational injuries, illnesses, or fatalities through the inclusion of prevention considerations into all designs that might impact workers.

While much progress has been made, there is still much to do. Since designing out occupational hazards is the most effective means of prevention, further effort to investigate and promote this concept is warranted. NIOSH intends to obtain new stakeholder input on the focus of the initiative and continue the initiative for another five years. Through continued and new partnerships with a range of stakeholders, the initiative will build on the progress to date in advancing prevention of occupational injuries, illnesses, and fatalities by designing out hazards.

John Howard, M.D.

Director, National Institute for

Occupational Safety and Health

Centers for Disease Control and Prevention 


\section{Executive Summary}

The national initiative on Prevention through Design (PtD) was launched in 2007 with the goal of designing out occupational hazards to protect workers. PtD involves all of the efforts to anticipate and design out hazards to workers in facilities, work methods and operations, processes, equipment, tools, products, materials, new technologies, and the organization of work [Schulte et al. 2008]. PtD utilizes the traditional hierarchy of controls by focusing on hazard elimination and substitution followed by risk minimization through the application of engineering controls and warning systems applied during design, re-design, and retrofit activities. In addition to reducing the risk of serious injury and illness, significant business costs savings are associated with hazard elimination and the application of engineering controls to minimize risks. As businesses adopt hazard control measures higher in the "hierarchy of controls," i.e., designing-out hazards and minimizing risks, business value increases (Figure 1). These improvements in business value are related not only to lower worker compensation rates and health care costs to care for injured workers but also to achieving faster time to market, improved operational efficiency, improved employee morale, decreased employee absenteeism and turnover, higher product quality, and increased market share. PtD also supports the application of administrative controls and personal protective equipment when they supplement or compliment an overall risk minimization strategy and include the appropriate program development, implementation, employee training and surveillance.

The ultimate objective of the PtD initiative is to achieve a cultural change so that designing out occupational hazards is the norm. Progress has been made the last six years in research, education, practice, and policy outcomes.

Research outcomes highlighted include a project initiated by NIOSH in partnership with ORCHSE Strategies, LLC (formerly Mercer, ORC Worldwide ${ }^{\mathrm{TM}}$ ) to determine the extent to which the policies

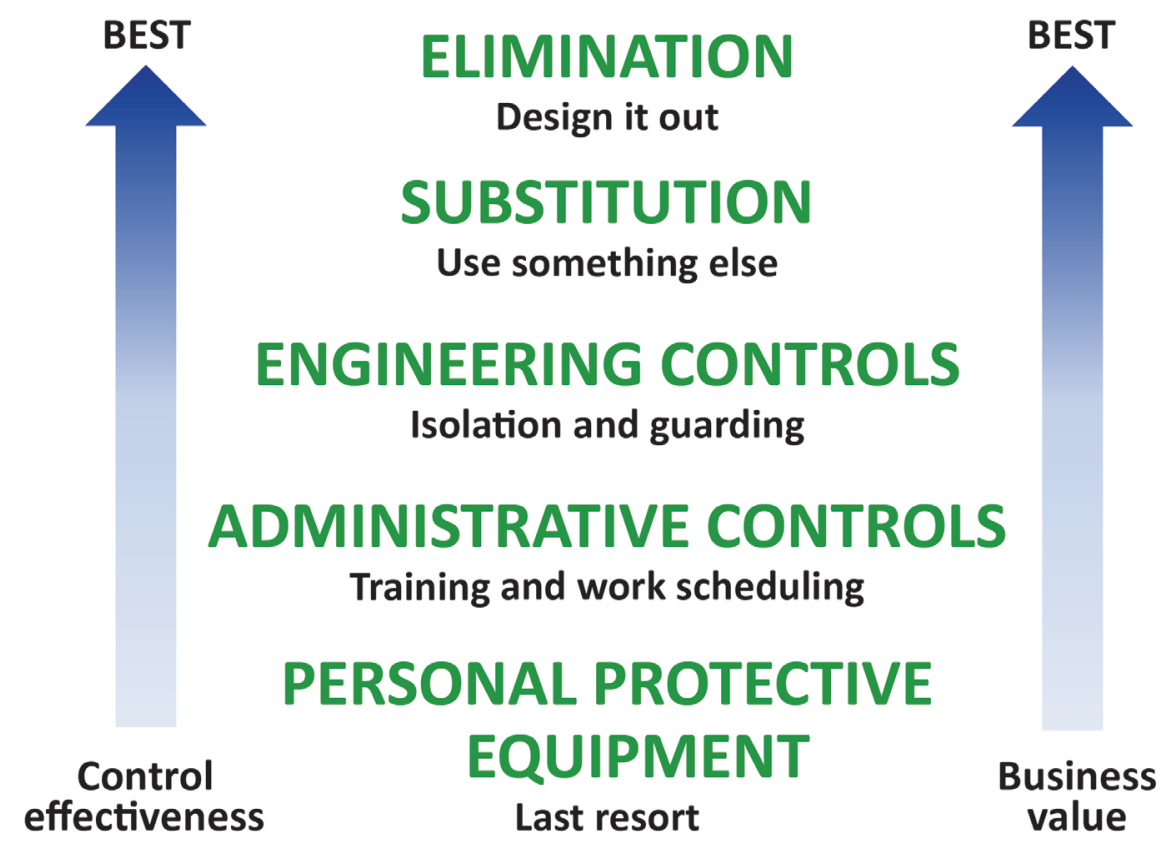

Figure 1. Prevention through Design using hierarchy of controls [Peterson 1973]. 
of large US-based multinational corporations stipulate that safety and health preventive measures be designed and built in, rather than added after a process has been put into operation. A survey was administered to ORC Fortune 200 member organizations to gather information on the extent to which $\mathrm{PtD}$ policy or practice is integrated into product design, machine design, plant layout, condition of premises, selection and specification of materials, production planning, and duties of managers and employees. The survey specifically captured information on company policies and management practices that address worker safety and health issues in the design or redesign of equipment, processes, or tools. Responses on the survey indicated that a majority (80\%) of companies were aware of PtD and $77 \%$ included $\mathrm{PtD}$ principles in their operations. Moreover, $40 \%$ of those responding indicated that they required their suppliers and contractors to have internal PtD programs [Biddle 2011; Newell and Biddle 2011].

Education outcomes of note include the inclusion of $\mathrm{PtD}$ principles in 10 safety management and engineering textbooks as well as the completion of four self-contained education modules targeting students majoring in Architectural, Civil, or Construction Engineering. Each module consists of a presentation file in an Adobe format, a PowerPoint presentation, and an instructor's manual. These have been completed for Architectural Design and Construction, Reinforced Concrete, Structural Steel Design and Mechanical-Electrical Systems.

Practice outcomes include 93 peer-reviewed journal articles cited over 720 times in the peer-reviewed scientific literature; the creation of a wiki to disseminate successful PtD concepts; and an outreach to industry that includes making the business case for PtD. One success story is the Construction Industry Institute research report, (RR101-11) Addressing Construction Worker Safety in the Project Design. The research effort identified and developed over 400 design suggestions that are available free to members of the Construction Industry Institute. The accumulated suggestions reflect all types of design disciplines, jobsite hazards, and construction components and systems. A computer program, titled "Design for Construction Safety ToolBox," was developed which incorporates the design suggestions accumulated. The program alerts the user to project-specific construction safety hazards and provides suggestions to eliminate or reduce those hazards during the design phase.

Policy outcomes have been numerous. PtD concepts have been added to over 25 consensus standards including those by American National Standards Institute (ANSI), American Society of Heating, Refrigerating and Air-Conditioning Engineers (ASHRAE), American Society of Safety Engineers (ASSE), American Industrial Hygiene Association (AIHA), Underwriters Laboratory (UL), Semiconductor Equipment and Materials International (SEMI), and the International Organization for Standardization (ISO). One highlight is that in 2011, the ASSE obtained approval from ANSI for ANSI/ASSE standard Z590.3, "Prevention through Design: Guidelines for Addressing Occupational Risks in Design and Redesign Processes". This standard provides guidance on including PtD concepts within an occupational safety and health (OSH) management system, and can be applied in any occupational setting.

Critical to making progress in institutionalizing PtD is to continue to influence educational systems in response to demands from industry and employees. NIOSH will assess the output of educational systems in terms of trained engineers, architects, designers, and purchasers. Additionally, the practice of OSH needs to include PtD principles in risk management systems. Until PtD is central to risk management, efforts to prevent occupational illness, injury, and death will be impaired and the cost of not implementing PtD will be significant. The progress made to date is a good foundation, but more progress is needed to ensure worker protection. 
Executive Summary

Acknowledgements

Abbreviations

Introduction

Research

Research Outcomes

Education

Education Outcomes

Practice

Practice Outcomes

Policy Outcomes

Small Business

Small Business Outcomes 


\section{Acknowledgements}

This report was developed by the scientists and staff of the National Institute for Occupational Safety and Health (NIOSH) who participate in the Prevention through Design (PtD) Initiative. Paul Schulte is the manager of the PtD National Occupational Research Agenda (NORA) cross-sector program. Those who contributed to the writing include Elyce Biddle, Pam Heckel, Donna Heidel, Laura Hodson, Lauralynn McKernan, and Paul Schulte. Former NIOSH employees Donna Heidel and Rick Rinehart are acknowledged for their strong coordinating efforts.

The PtD Initiative acknowledges the contributions of Brian Hennigan and Nancy Willman of Willman Design, and Vanessa Williams of NIOSH for their graphic design and production services. In addition, it expresses special appreciation for those external partners who contributed to the writing and review (below). Thanks are also extended to the participants and contributors to the PtD Initiative (pages 24-25).

John Gambatese, Ph.D, P.E.

Oregon State University

Corvallis, OR

Fred Manuele, CSP, P.E.

SBC Global

Arlington Heights, IL

Jim McGlothlin, Ph.D, C.P.E.

Purdue University

West Lafayette, IN

Georgi Popov, Ph.D.

University of Central Missouri

Warrensburg, MO

Margaret Quinn, Sc.D., CIH

University of Massachusetts, Lowell

Lowell, MA

Scott Schneider, M.S.

Laborers' Health and Safety Fund of North America

Washington D.C.

Mike Taubitz, BSME, M.A

FDR Safety

Fenton, MI 


\section{Abbreviations}

ABET Accreditation Board for Engineering and Technology

ACGIH American Conference of Governmental Industrial Hygienists

AEM Association of Equipment Manufacturers

AIHA American Industrial Hygiene Association

AIHce American Industrial Hygiene conference and exposition

ANSI American National Standards Institute

AP accredited professional

ASHRAE American Society of Heating, Refrigerating and Air-Conditioning Engineers

ASCE American Society of Civil Engineers

ASSE American Society of Safety Engineers

CDM Construction, Design, and Manufacturing

CIB Chartered Institute of Building

CPWR Center for Construction Research and Training

CURT Construction Users Roundtable ${ }^{\varpi}$

EHS environment, health, safety

FACE Fatality Assessment and Control Evaluation

HHE health hazard evaluation

ISO International Organization for Standardization

LEED Leadership in Energy and Environmental Design

$\mathrm{MMH}$ manual material handling

NCEES National Council of Examiners of Engineers and Surveyors

NFPA National Fire Protection Association

NIOSH National Institute for Occupational Safety and Health

NORA National Occupational Research Agenda

NSC National Safety Council

NTRC Nanotechnology Research Center

OEB occupational exposure band

OEL occupational exposure limit

$\mathrm{OSH} \quad$ occupational safety and health

OSHA Occupational Safety and Health Administration

PDC professional development course

PMMI Packaging Machinery Manufacturers Institute

PtD Prevention through Design 


$\begin{array}{ll}\text { r2p } & \text { research to practice } \\ \text { REL } & \text { recommended exposure limit } \\ \text { SEMI } & \text { Semiconductor Equipment and Materials International } \\ \text { TSCA } & \text { Toxic Substances Control Act } \\ \text { UK } & \text { United Kingdom } \\ \text { UL } & \text { Underwriters Laboratory } \\ \text { US } & \text { United States } \\ \text { USGBC } & \text { United States Green Building Council } \\ \text { VOC } & \text { volatile organic compound }\end{array}$




\section{Introduction}

The national initiative on Prevention through Design (PtD), was launched in 2007 with the goal of designing out occupational hazards to protect workers. PtD encompasses all of the efforts to anticipate and design out hazards to workers in facilities, work methods and operations, processes, equipment, tools, products, new technologies, and the organization of work [Schulte et al. 2008]. Too often, workers (including those who perform maintenance tasks) have not been considered in the design process. The focus of $\mathrm{PtD}$ is on workers who execute the designs or have to work with the products of the design. The initiative has been developed to support designing out hazards, the most reliable and effective type of prevention. PtD can be practiced at all levels of the hierarchy of controls, but it is most effective as the means to eliminate hazards.

The initiative, built on past efforts and a critical mass of supporters, was promoted by the National Institute for Occupational Safety and Health (NIOSH) and various stakeholders (Table 1). Subsequently, a strategic plan was developed by the stakeholders in a series of public meetings to gain a wide range of input (Figure 2). Specific goals were developed to support each of the economic sectors identified as part of the National Occupational Research Agenda (NORA) [NIOSH 2011]. Many issues raised at the sector level apply to more than one industry. Since 2008, the strategic plan has served as the basis

\section{Prevention through Design National Initiative}

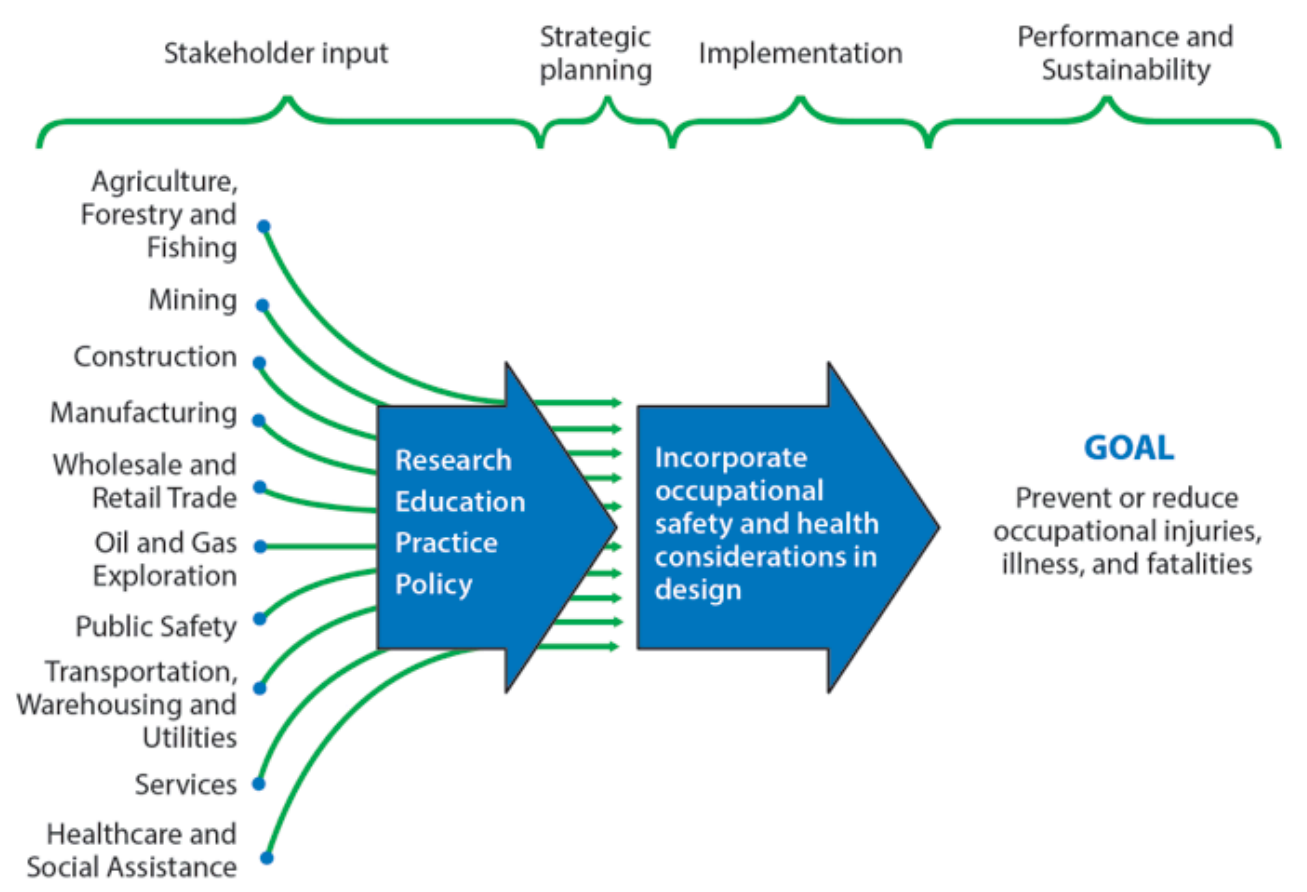

Timeline

Figure 2. Development of the PTD strategic plan [NIOSH 2011]. 


\title{
Table 1. Founding Partners in the PtD Initiative
}

\author{
American Industrial Hygiene Association (AlHA) \\ American Society of Safety Engineers (ASSE) \\ Association of Equipment Manufacturers (AEM) \\ The Center for Construction Research and Training (CPWR) \\ Kaiser Permanente \\ Liberty Mutual \\ National Safety Council (NSC) \\ Occupational Safety and Health Administration (OSHA) \\ ORCHSE Strategies, LLC (formerly Mercer, ORC Worldwide ${ }^{T M}$ )
}

Regenstrief Center for Healthcare Engineering

for planning and implementation. The plan has five strategic goals, 35 intermediate goals, and 52 related research activities. These goals and objectives were organized into four overarching areas: research, education, practice, and policy. Small business was added as an additional focus for goal development to address the unique challenges of applying PtD methods to small business operations, processes, and environments. Each of these overarching areas, as well as the small business focus area, is supported by a strategic goal. Details about specific activities for accomplishing each goal, as well as performance measures and time frames, were included in the PtD Plan for the National Initiative [NIOSH 2011], www.cdc. gov/niosh/ docs/2011-121/ (Figure 3). The initiative was developed to cover the period of 2007 to 2014 . The ultimate objective is to achieve a cultural change so that designing out occupational hazards is considered the norm. Since the inception of PtD, NIOSH has invested over \$26 million dollars in the initiative, $\$ 23.3$ million $^{*}$ in extramural pro-

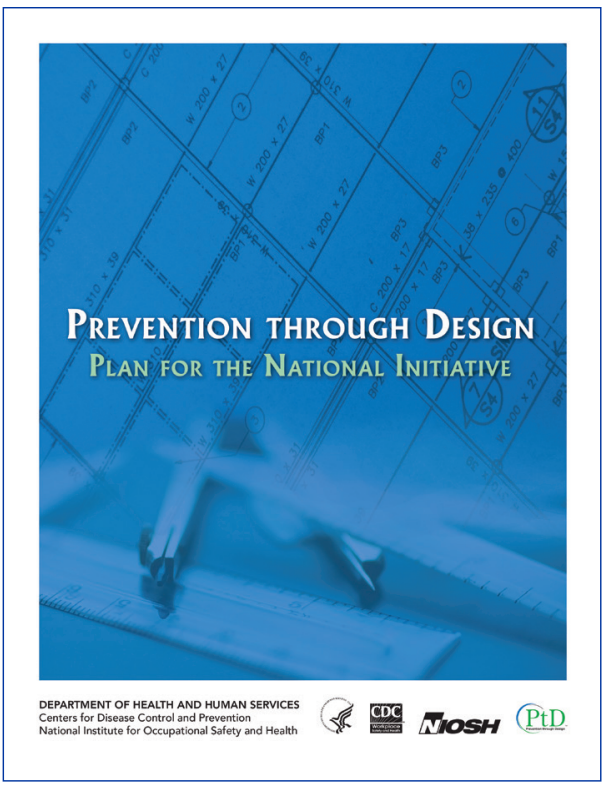

Figure 3. The Prevention through Design Plan for the National Initiative document cover. grams, and $\$ 2.8$ million in intramural programs (Figure 4). At this time, it is useful to take stock of the progress of the initiative and to identify what still needs to be accomplished. This report on the initiative covers efforts through 2013. For each of the overarching areas, the progress and the remaining work will be described.

${ }^{*}$ This represents all extramural projects that in any way include PtD. Projects may not necessarily be $100 \%$ $\mathrm{PtD}$, but rather a portion of the research includes $\mathrm{PtD}$. 


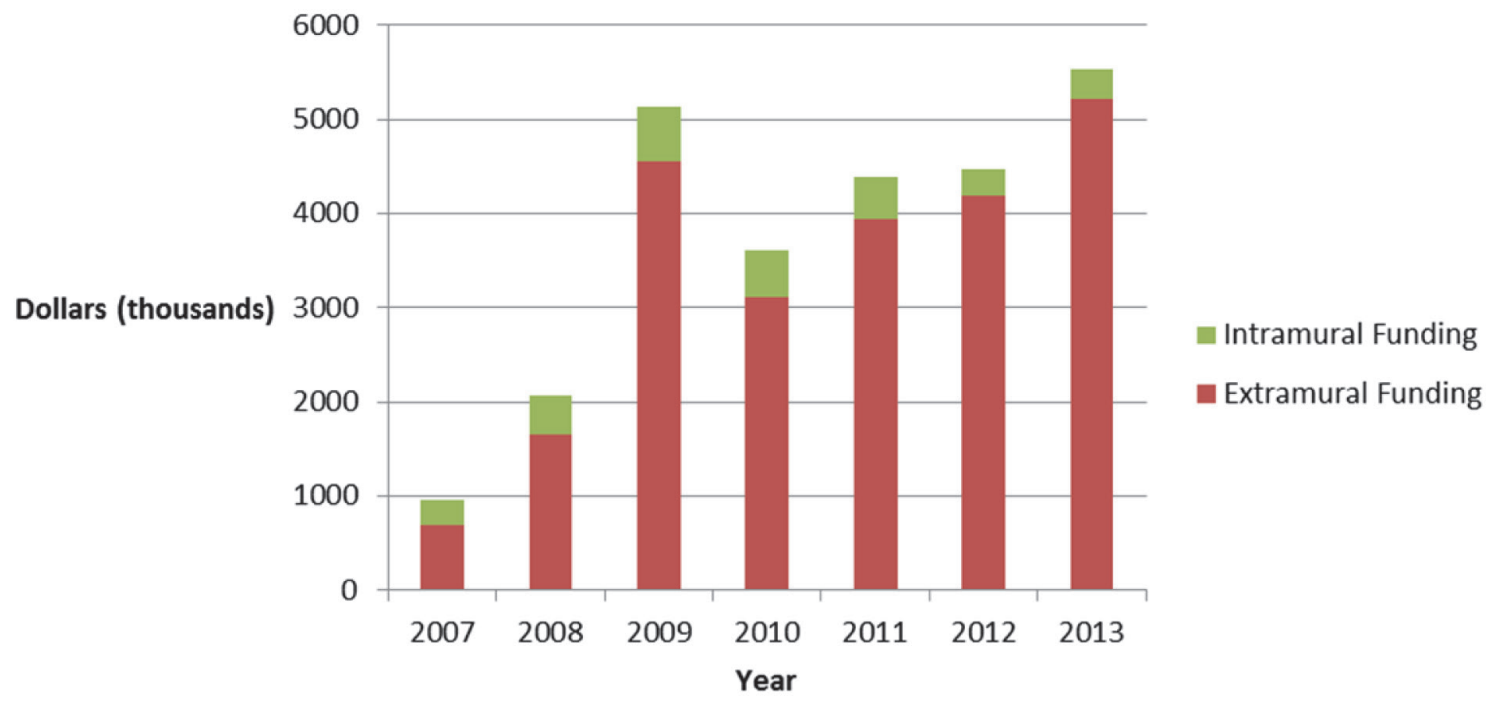

Figure 4. NIOSH PtD investment by year.

\section{Research}

\section{Strategic Goal}

Research will establish the value of adopted PtD interventions, address existing design-related challenges, and suggest areas for future research.

There is a need for research on design factors that effectively reduce occupational morbidity and mortality; metrics that assess the impact of these design factors; methods that diffuse effective designs; and, economic and business issues, specifically to address these questions:

What evidence indicates that design will effectively eliminate hazards and reduce risks to workers? What role does design play in each sector's serious injury, illness, fatality, and exposure experience? What are the motivators for, and barriers to, effective implementation of PtD? Which business cases demonstrate the effectiveness of implementing PtD? Which factors contribute to a building a culture of safety?

\section{Research Outcomes}

One of the first research projects was undertaken to study where designing out hazards had been mandated by regulation. This was the case in the British construction industry, which developed such a mandate in 1994, www.hse.gov.uk/consult/condocs/cd200.pdf [Health \& Safety Commission 1994; Jeffrey and Douglas 1994]. The study benchmarked the role of the designer in the United Kingdom (UK) in identifying those areas where the prevention of illness and injuries through design would have the greatest impact on work processes. Fourteen focus group interviews were conducted in London and the surrounding area by NIOSH representatives and a contractor from Loughborough University. The focus groups were comprised of individuals who were employed by construction industry 


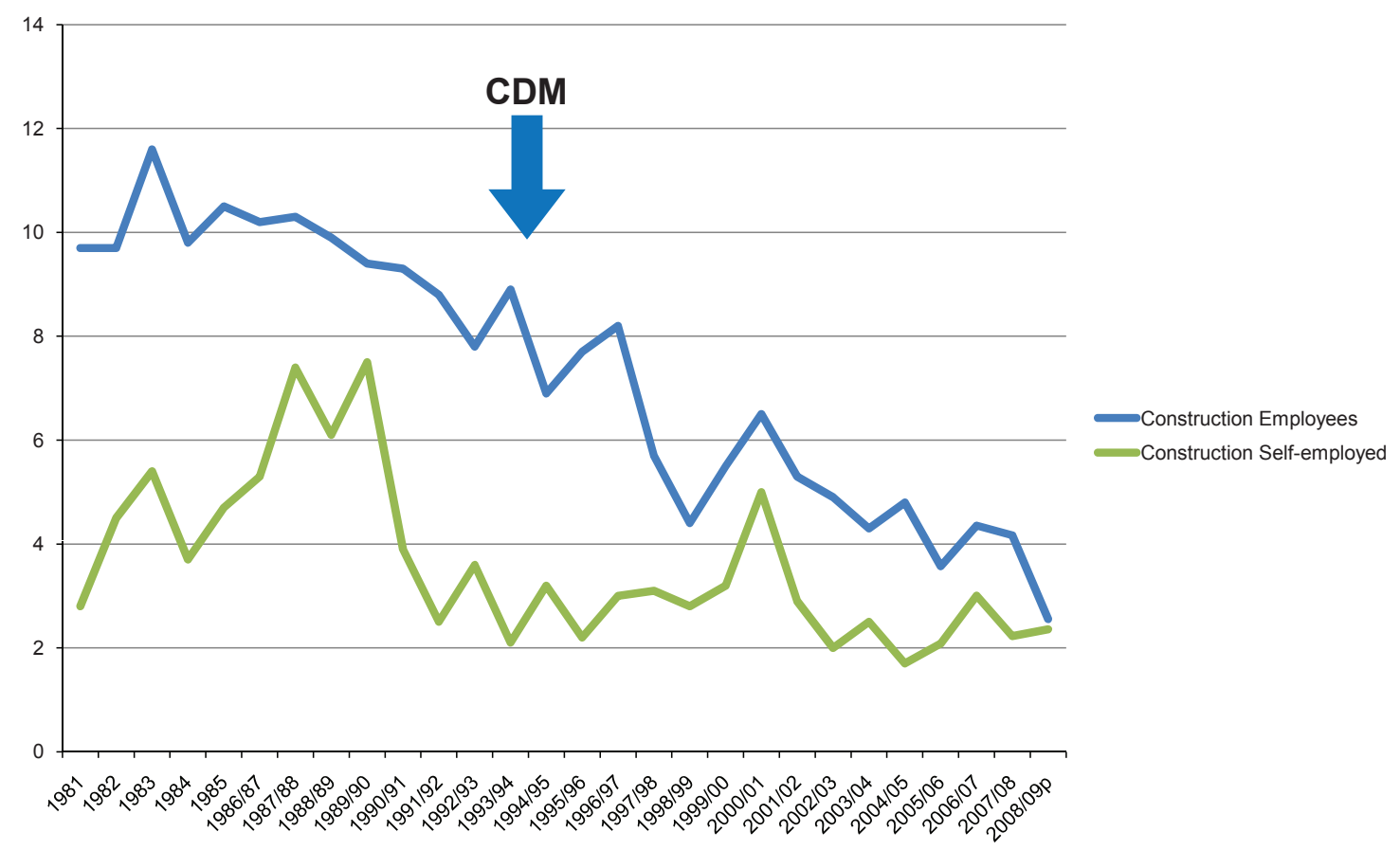

Figure 5. Fatal injury rates in the UK before and after the Construction, Design, and Management (CDM) regulations [Gambatese 2013].

professional organizations in the UK: Chartered Institute of Building (CIB), Royal Institute of British Architects, Institution of Civil Engineers, British Safety Council, and Association for Project Safety. The questions explored PtD concepts, their application and their impact.

The results from the focus group interviews were presented at the 2009 CIB conference in Melbourne [Gambatese et al. 2009]. In addition, the study included an online survey of the UK construction industry to gather input from a broader audience. The survey provided information on the application of PtD from 228 respondents who represent a wide spectrum of the industry. Two supplemental activities were added to the study. These were a focused evaluation of the PtD activities on construction projects at the Sellafield nuclear facility in the UK, and additional focus group interviews of construction industry personnel in Australia where similar PtD legislation is in place. Fatal injury rates for UK construction workers have declined since the adaptation of the Construction Design and Management (CDM) regulation in 1994 (Figure 5). A report on the study [Gambatese 2013] identifies and recommends consideration of four attributes related to the adoption of PtD in the US: knowledge, desire (motivation), ability, and execution. Each attribute addresses a fundamental need for affecting positive change and enabling desired outcomes. The research findings reveal that each of the attributes needs to be fulfilled in some way for $\mathrm{PtD}$ to be successful. The report presents a variety of components to address and accentuate each attribute within the context of PtD in the US construction industry. Selection and pursuit of each component depends on the resources available and the industry environment.

A concurrent project was initiated by NIOSH in partnership with ORCHSE Strategies, LLC to determine the extent to which the policies of large US-based multinational corporations stipulate that safety and health preventive measures be designed and built in, rather than added after a process has been put into operation. A survey was administered to ORC Fortune 200 member organizations to 
gather information on the extent to which PtD policy or practice is integrated into product design, machine design, plant layout, condition of premises, selection and specification of materials, production planning, and duties of managers and employees. The survey specifically captured information on company policies and management practices that address worker safety and health issues in the design or redesign of equipment, processes, or tools. Responses on the survey indicated that a majority (80\%) of companies were aware of PtD and $77 \%$ included PtD principles in their operations. Moreover, $40 \%$ of those responding indicated that they required their suppliers and contractors to have internal PtD programs [Biddle 2011; Newell and Biddle 2011].

Another area of research under the initiative included an investigation of five $\mathrm{PtD}$ solutions in practice in the construction industry: (1) concrete straps for fall arrest; (2) increased height of roof parapets; (3) placement of electrical wiring in slabs and underground; (4) concrete imbeds for guardrail support; and (5) a soil retention system with railing. Each solution consists of a detailed description of the design, benefits, and limitations to illustrate the application of $\mathrm{PtD}$ in practice. These solutions will be presented in a series of NIOSH documents called Workplace Design Solutions.

Research continues in the area of risk assessment with the development of a design risk rating system. A survey of building trades professionals was used to quantify the risk associated with specific tasks and materials used to construct a building. Tasks required to install components were assigned a risk rating on a Likert scale. Individual tasks were combined to generate the procedure for constructing larger components. The risk values associated with constructing each component allow for architects and engineers to select and modify their designs to reach a desired risk level. The research will result in construction safety risk factors for all of the alternative designs for the elements of typical commercial buildings. A computer model of the design risk rating system is being built for pilot study testing in 2014.

The PtD initiative is also focused on designing out occupational hazards in sustainability efforts. In December 2009, NIOSH held the "Making Green Jobs Safe Workshop" to identify which jobs were considered "green" and to raise awareness of the hazards associated with the construction and maintenance of "green" building elements. In 2010, a NIOSH-supported research project at Oregon State University examined the Leadership in Energy and Environmental Design (LEED) credits for certification of new buildings. Another PtD study conducted at the University of Massachusetts Lowell and presented at the NIOSH PtD conference in 2011, evaluated newly constructed LEED certified buildings to identify OSH hazards to preventive maintenance workers resulting from the design of green building features. Several serious OSH hazards related to equipment and building design were found, all of which could be eliminated in future LEED building design [Omar et al. 2013]. The report identified specific credits that improved worker safety during construction and after occupancy and noted those credits that might inadvertently increase the risk of illness and injury. The researchers also drafted an example pilot credit which can be used to acknowledge the importance of PtD to sustainability and incorporate PtD within the LEED rating system. In 2012, NIOSH met with the US Green Building Council (USGBC) to discuss the inclusion of worker health and safety into LEED credits for certification. Just as the media continue to celebrate the erection of Platinum LEED certified buildings, NIOSH is actively attempting to introduce PtD Best Practices into the LEED rating system. Both NIOSH and USGBC are advocating for safe and healthy green jobs while seeking a path forward to sustainability. Workers at every stage of the capital project process may encounter hazards unique to new materials, processes, or equipment. The PtD initiative is aimed at identifying these hazards.

NIOSH is working with various external partners to assess existing occupational safety and health surveillance and data systems for their potential to identify design-related factors that contribute to work-related injuries and illnesses. The extent to which existing systems identify design-related 
factors is unknown. The literature is sparse. A decade ago, the Australian Government investigated the "design-related" root causes of work-related fatalities that occurred from 2000 to 2002. Seventyseven $(37 \%)$ of the 210 identified workplace fatalities definitely or probably involved design-related issues. In another 29 fatalities (14\%), the circumstances suggested that design issues may have been involved [Driscoll 2008]. In addition to the limited number of efforts, many are not comprehensive, but focus on only one particular system or one particular design factor. The newest NIOSH PtD project will provide for a comprehensive assessment through the completion of three specific aims: (1) examine existing occupational safety and health surveillance systems for the potential to guide PtD efforts, (2) examine other systems that contain occupational safety and health data, and (3) develop and disseminate assessment results.

Identification of a specific parameter to quantify the relationship between adoption of PtD concepts and reduction of illness/injury rates is still a challenge. Although dozens of scientists are involved with $\mathrm{PtD}$ research, there is not yet a comprehensive picture of the collective benefit of integration of PtD concepts. Several case studies have demonstrated a positive return on investment for specific design interventions. There are numerous examples of lessons learned through operations and maintenance, which when front loaded into the conceptual design phase of new facilities, processes, and equipment, are effective in eliminating the unsafe condition. This is especially true for ergonomic interventions.

\section{Education}

\section{Strategic Goal}

In July 2008, Directors of NIOSH training grant programs met with key NIOSH staff members to delineate the educational goal for PtD:

Designers, engineers, machinery and equipment manufacturers, health and safety professionals, business leaders, and workers understand PtD methods and apply this knowledge and skills to the design and re-design of new and existing facilities, processes, equipment, tools, and organization of work.

Education focuses on motivating and equipping professional communities to continually increase their capacity to identify health hazards and assess and minimize risks for worker safety and health. Integration of PtD will occur through enhanced design and engineering curricula as well as improved professional accreditation programs that value PtD knowledge and skills and include them in their competency assessments. Making business leaders aware of the potential for increasing company profitability by incorporating PtD methods into their systems and processes is also an important component.

$\mathrm{PtD}$ requires the development and implementation of a broad educational framework adapted to the full range of occupational disciplines and educational settings involved in educational transfer. The educational objectives and content vary significantly according to the individual disciplines or education setting. For example, the educational needs of the mechanical engineer vary from those of the architect, industrial designer, purchasing agent, or finance professional. However, common PtD themes are woven into the broad educational framework. Fundamental to the concept of risk management is the ability to accurately assess risk and recommend acceptable risk levels through the application of the hierarchy of controls. Educating professionals in all design-related occupational disciplines on determination of acceptable risk and subsequent communication to management is vital to the success of PtD. Furthermore, the educational framework must address the needs of students at the beginning of their careers, as well as those of experienced professionals. For students, PtD educational 
material could be integrated into existing courses, textbooks, and certifications. For experienced professionals, PtD concepts could be delivered via professional development courses, continuing education seminars, and journal publications. In addition to focusing on the supply (capacity building) aspect in engineering education there is also need to address the demand side. Employers must be stimulated to seek new employees with knowledge of PtD principles and practices. PtD knowledge, skills and information must also reach small business owners who may not have access to professional development courses. This may be accomplished by utilizing various business and trade associations as well as through product and service suppliers. Finally, but no less important, PtD education must reach the worker. Novel educational formats, such as web-based video clips, could broaden outreach to workers in all industrial sectors and in large and small workplaces. Moreover, workers often know the strengths and weaknesses of the facilities and equipment they work with and can contribute to the design or redesign process.

\section{Education Outcomes}

Although some graduate programs include ergonomics, most undergraduate engineering curricula do not teach the tools and techniques needed for PtD. This gap in education requires that industry "retrofit" new engineers to the concepts, standards, and thinking for PtD to occur. Unfortunately, where companies are not familiar with $\mathrm{PtD}$, the missed opportunity to eliminate and mitigate hazards during concept and design are missed. During the past 30 years, dialogue via symposia among educators, labor, business, and industry leaders concluded that safety and health education should be infused throughout the engineering curricula, rather than being offered solely in stand-alone courses for Safety Engineering, Industrial Hygiene, and Occupational Medicine. The PtD initiative to address this situation involves the development of content for textbooks, the creation of education modules, and the presentation of PtD concepts at workshops, conferences, and seminars.

\section{Textbooks}

NIOSH is working with major engineering textbook publishers to diffuse PtD principles into engineering textbooks through case studies, homework problems, and examples (Figure 6). The process is as follows. The publishing editor identifies textbooks with significant market share in the United States that are being updated. These textbooks in various engineering subspecialties reach thousands of students annually. Authors who are willing to work with NIOSH request PtD content relevant to the subject. External subject matter experts with textbook-specific engineering and PtD expertise provide input to authors. The NIOSH-led effort should catalyze other groups to expand, replicate, and improve the project independently of NIOSH.

The textbook project began in 2008 when NIOSH met with editorial staff at J. Wiley \& Sons to discuss the inclusion of PtD concepts into engineering textbooks. Sixty textbooks were initially identified and reviewed. Data elements included the subspecialty areas of engineering covered by the books, planned revision dates, annual sales volume, specific examples of $\mathrm{PtD}$ concepts currently included in the text, and missed opportunities for presenting PtD concepts. Of the reviewed textbooks, 15 were selected. The authors were approached and encouraged to utilize PtD examples.

A similar effort was made with regards to other publishing houses. Editors at Taylor \& Frances Group's CRC Press and McGraw Hill agreed to collaborate to push the initiative. Additional content was developed for textbooks in the areas of structural steel, reinforced concrete, mechanical and 

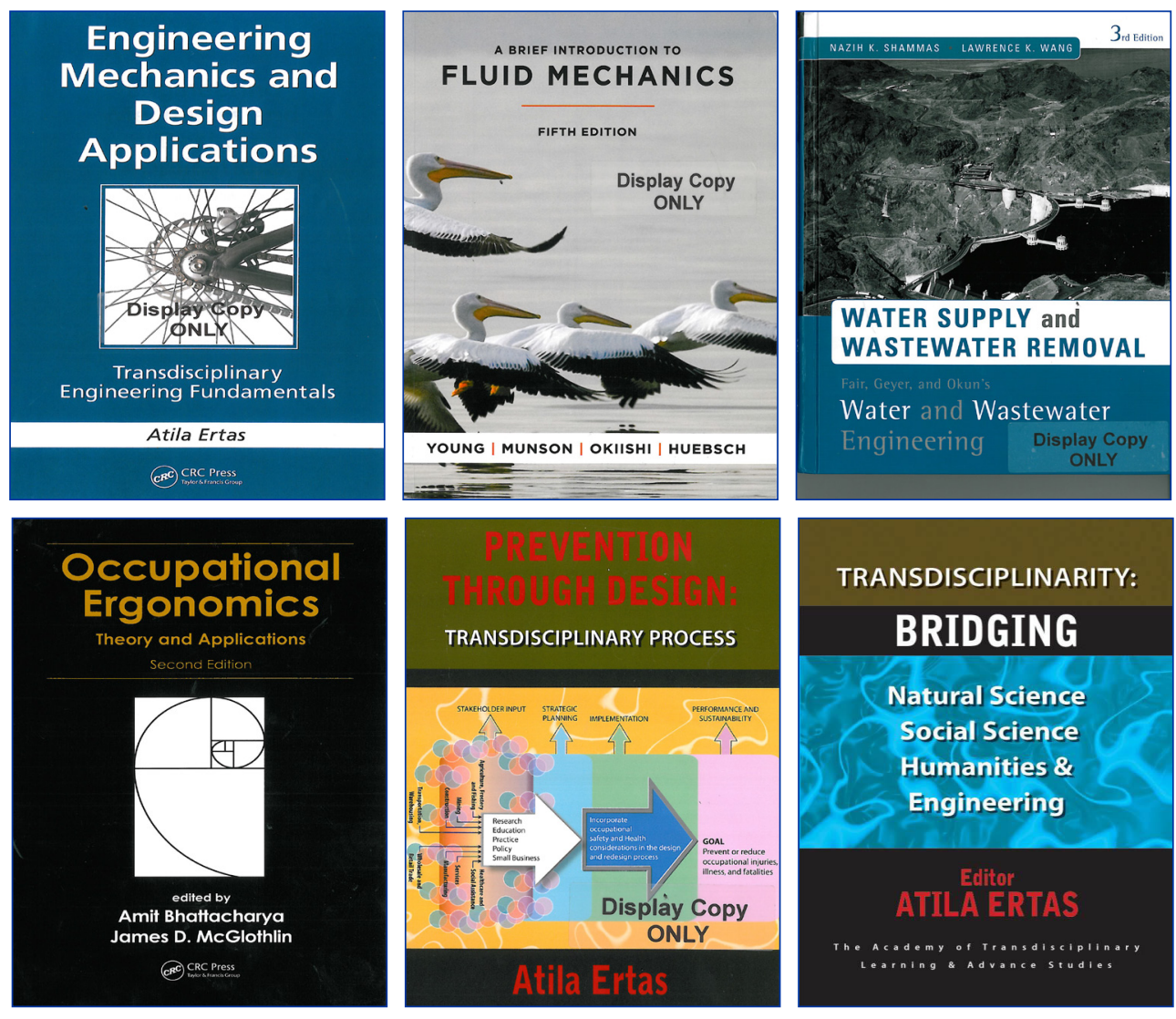

Figure 6. Covers of textbooks that include PtD content.

electrical building systems, construction management, traffic management, green building features, architectural design, risk assessment and reliability, chemical process safety, manufacturing equipment, agricultural chemicals and equipment, and laboratory safety.

As listed in Table 2, the first NIOSH collaboration on a PtD textbook was with noted safety expert Fred Manuele in February, 2008. Dr. Atila Ertas at Texas Tech compiled a summary of PtD theory and published it in 2010. In October 2010, another textbook was published. Dr. Nazih K. Shammas included several $\mathrm{PtD}$ case studies in his water and wastewater textbook, some with information from NIOSH fatality assessment and control evaluation (FACE) reports. He also wrote a standalone chapter (Chapter 21) on hazard identification, systems safety, and other risk assessment techniques for engineers. Dr. Lou DiBeradinis from the Massachusetts Institute of Technology reviewed Chapter 21 and recommended inclusion of examples from the "Handbook of Health and Safety" (1999). Chris Griffin, a doctoral student in the Mechanical and Aerospace Engineering Department at West Virginia University developed PtD content for a textbook on fluid mechanics. A second textbook by Dr. Shammas contains ten PtD/OSH examples developed by Carolyn Jones, from the City of San Francisco water authority. Dr. Ertas published his second booklet in 2011. This was soon followed by a PtD textbook for mechanical engineers. James D. McGlothlin, professor and Director of the graduate program in Occupational and Environmental Health Sciences at Purdue University, collaborated with Professor Amit Bhattacharya at the University of Cincinnati to include PtD concepts in the second edition of their ergonomics textbook. Finally, noted pioneer in instructional methodology, Richard M. Felder agreed to include PtD concepts in the next revision of his successful textbook, Elementary Principles 


\section{Table 2. Selected Textbooks including PtD Concepts}

Manuele FA [2008]. Advanced safety management: focusing on Z10 and serious injury prevention. 1st ed. New York: John Wiley \& Sons.

Ertas A [2010]. Prevention through design: transdisciplinary process. The ATLAS.org. ISBN: 0-9778129-4-4.

Young DF, Munson BR, Okiishi TH, Huebsch WW [2010]. A brief introduction to fluid mechanics. 5th ed. New York: John Wiley \& Sons.

Shammas NK, Wang LK [2011]. Fair, geyer, and okun's water and wastewater engineering: water supply and wastewater removal. 3rd ed. New York: John Wiley \& Sons.

Wang LK, Hung YT, Shammas NK, editors [2011]. Waste treatment in the mining and chemicals manufacturing industries. Boca Raton: CRC Press.

Ertas A [2011]. Transdisciplinarity: bridging social science, natural science, humanities and engineering. The ATLAS.org. ISBN: 0-9778129-3-6.

Ertas A [2011]. Engineering mechanics and design applications: transdisciplinary engineering fundamentals. Boca Raton: CRC Press.

Bhattacharya A, McGlothlin JD [2012]. Occupational ergonomics, theory and applications. 2nd ed. Boca Raton: CRC Press.

Main B [2012]. Risk assessment: challenges and opportunities. ISBN 9780-9741248-2-7

Manuele FA [2013]. On the practice of safety. 4th ed. New York: John Wiley \& Sons

Felder RM, Rousseau RW [In press]. Elementary principles of chemical processes. 4th ed. New York: John Wiley \& Sons.

of Chemical Processes. Homework problems and examples were developed by Carol Clinton, Ph.D., LEED AP. The fourth edition is awaiting publication by J. Wiley \& Sons. The publication rate for hardback textbooks has slowed as the publishers convert to electronic media; however, as of April 2013 a literature search identified 68 books containing PtD concepts. NIOSH anticipates the availability of PtD content in formats accessible to eReaders, Smartphones, tablets, and other platforms and expects future textbooks to be compatible with these devices.

\section{Curricula}

Over the past five years, more than 30 universities have expressed interest in incorporating PtD into their undergraduate engineering courses. Notable are interdisciplinary PtD courses at Virginia Tech; a Master's degree program at University of Alabama at Birmingham; continuing education classes at Harvard University; and engineering classes at Virginia Commonwealth, University of Massachusetts Lowell, Bucknell University, Oregon State University, Purdue University, and the University of Utah. 
Interest in ergonomics has increased because of the well-publicized payoff of ergonomic interventions. Several degree programs in Safety Engineering and in Biomedical Engineering have been accredited by ABET, formerly known as the Accreditation Board for Engineering and Technology. Graduate programs in Industrial Hygiene and Occupational Medicine continue to attract engineers. Research funded by NIOSH in 2011 revealed that (1) adding PtD language to ABET criteria was broadly supported; (2) the best approach may be adding PtD phrases rather than simply the terms safety or PtD; and (3) the implementation process may take several years. NIOSH will continue to work with the American Society of Civil Engineers (ASCE) to advocate for PtD in civil engineering.

\section{Education Modules}

NIOSH is developing education modules to convey PtD concepts to undergraduate engineers in three or more lectures. The first four modules target students majoring in Architectural, Civil, or Construction Engineering. Each module consists of a presentation file in an Adobe format, a PowerPoint presentation, and an instructor's manual.

The Architectural Design and Construction Education Module covers site planning and excavation, specific building elements such as skylights, solar panels and green roofs, general safety considerations, and hazards associated with decommissioning a building.

The Reinforced Concrete Design Module covers concrete design, detailing, fabrication, and erection processes. Examples are provided to enable structural engineers and detailers to incorporate PtD into their reinforced concrete designs.

The Structural Steel Design Education Module covers steel design, detailing, fabrication, and erection processes. Examples are provided to enable structural engineers and detailers to incorporate PtD into their steel designs.

The Mechanical-Electrical Systems Education Module covers electrical hazards. A wind farm case study demonstrates effective PtD solutions for fall protection. The research facility case study identifies PtD concepts applied to mechanical-electrical systems safety. This module contains five short videos in the PowerPoint version. In the Adobe version, links are provided to access captioned videos through the internet.

Recently published and future modules can be downloaded from the NIOSH Web site: www.cdc.gov/niosh/programs/ptdesign/pubs.html

Four more education modules are in process. Working titles are: Chemical Process Safety, Risk Assessment and Reliability for Biomedical Engineers, Hazard Identification for Agricultural Engineers, and Manufacturing and Industrial Engineering. Additional modules are planned in Safe Nano Design, Lifting and Packaging Design, and Protecting Human Capital. The plan is to disseminate them through NIOSH stakeholders and university partners. NIOSH is working with engineering professional organizations to share real classroom examples of PtD applications. NIOSH has provided a copy of the modules to the National Council of Examiners of Engineers and Surveyors (NCEES), the organization that develops the Fundamentals Exam, a comprehensive exam for graduating engineers. The PtD Council and NORA Sector Councils will be utilized to announce the availability of these modules. NIOSH expects they will be used by industry and academia alike. 


\section{Conferences and Symposia}

As shown in Table 3, numerous scientific and professional conferences have involved promotion of PtD. In December 2009, the "Making Green Jobs Safe," workshop was held to develop recommendations for workers in the green jobs industries and for workers installing green building elements (Figure 7). Representatives from the OSH and environmental communities within industry, labor, academia, government agencies, and nongovernment organizations met to consider how to emphasize that green jobs should be safe and healthy for workers. The most discussed aspects of green jobs are (1) the need for increased awareness by employers about how their economic activity impacts environmental resources, (2) the subsequent need to mitigate these negative environmental impacts, and (3) the need to communicate this information to workers and consumers. The purpose of this workshop was to develop a framework and plan for adding to this discussion specifically how to make green jobs safe. It also sought to demonstrate that OSH and environmental protection are overlapping, equally laudable, achievable goals. A summary of the workshop, including 48 compelling activities pertaining to green jobs and sustainable design, is available at www.cdc.gov/niosh/docs/2011-201/pdfs/2011-201.pdf.

Another conference was held in Washington, DC, in late August 2011, at the midpoint of the initiative. The goal of "Prevention through Design: A New Way of Doing Business" was to take stock of the nation's progress in improving worker safety and health through the inclusion of prevention methods in all designs that impact workers. The conference brought together PtD leaders from industry, labor, academia, government agencies, and professional organizations to showcase research results, engineering education enhancements, successful stakeholder practices, and policy developments and advancements. Significant progress has been made in advancing the prevention of occupational injuries, illnesses, and fatalities by eliminating hazards and minimizing risks to workers in the design and redesign of facilities, work methods, processes, equipment, and products. The proceedings were summarized in six articles published in the 2013 January and March issues of Professional Safety. Through the generosity of the American Society of Safety Engineers, the articles are accessible through the NIOSH website www.cdc.gov/niosh/programs/ptdesign/pubs.html.

In addition, NIOSH hosted the first Design for Safety and Health student contest, which challenged undergraduate engineering and industrial design student teams to develop ways to make the workplace safer by applying PtD concepts. Successful designs not only reduce the risk of workplace injuries and illnesses but also add business value by improving business processes and productivity and creating desirable workplaces. NIOSH recruited participants with the help of academic deans. The students were asked to identify features of their designs that would improve worker health and safety and to describe how the design could reduce risk of occupational fatalities, serious injuries, or illnesses. These elements were included in an abstract and paper describing the project and how PtD concepts were incorporated into the design process. The projects centered around three themes: Facility/ Building/Public Space; Process/Product; and Devise/Machine Tool. Researchers and technical staff at 


\section{Table 3. Selected Conferences including PtD topics}

Prevention through Design Virtual Symposium, American Society of Safety Engineers, February 20-21, 2013.

Safe Nano Design, College of Nanoscale Science and Engineering (CNSE), August 14-16, 2012, Albany, NY

Prevention Through Design Conference: A New Way of Doing Business; A Report on the National Initiative, August 22-24, 2011, Washington, DC

National Safety Council, National Occupational Injury Research Symposium. October 18-20, 2011, Morgantown, WV

Making Green Jobs Safe, December 14-16, 2009, Washington, DC

Toxics Use Reduction Act (TURA) 20th Anniversary Symposium and Continuing Education Conference, November 4, 2009, Bedford, MA

National Environmental Public Health Conference, October 26-28, 2009, Atlanta, GA

97th Annual National Safety Council Congress \& Expo, October 23-30, 2009, Orlando, FL

25th Annual National Voluntary Protection Programs Participants' Association (VPPPA) Conference, August 24-27, 2009, Henry B. Gonzalez Convention Center, San Antonio, TX

American Industrial Hygiene Conference and Exposition (AlHce), May 31-June 4, 2009, Toronto, Canada

CleanMed 2009, Prevention through Design in the Health Care Sector, May 19-20, 2009, Chicago, IL

48th Navy and Marine Corps Public Health Conference, March 20-26, 2009, Hampton, VA

International Mechanical Engineers Conference and Exposition (IMECE), November 5, 2008, Boston, MA

National Safety Council, International Symposium on Distracted Driving, October 14-15, 2008, Arlington, VA

ORC Worldwide Executive Business Issues Forum, October 2, 2008, St. Louis, MO

Workshop Meeting of Occupational Safety/Ergonomics/Injury Prevention NIOSH Training Grant Program Directors, Infusing PtD Principles into University Engineering and H\&S Curricula, July 10, 2008, Pittsburgh, PA

American Industrial Hygiene Conference and Exposition (AlHce), May 31-June 5, 2008, Minneapolis, MN

Association of Equipment Manufacturers (AEM) Product Safety Seminar, April 21-23, 2008, Dallas, TX 
NIOSH reviewed the submitted papers for their occupational health and safety applicability. The three projects that best represented PtD principles in design were selected to be presented by the students at the August 2011 conference (PtD: A New Way of Doing Business). The students presented posters of their projects and held a question and answer session at the evening welcoming ceremony. They also presented their projects as the Keynote Address during the conference lunch. Judges from academia and industry evaluated the projects for design intent and commercial appeal. Getting students actively involved in the concepts of $\mathrm{PtD}$ ensures a future workforce that strives to eliminate hazards and risks to workers during the design process.

More recently, in 2012, PtD was the theme of the "Engineer 2020" program at Purdue University. This program strives to assure that the engineers of the future are technically proficient engineering graduates whose education extends into many other areas-both technical and non-technical with critical skill including a firm grasp on PtD principles. The university made available small grants to fund student research in design to address specific occupational hazards. The grant winners presented their work during the program.

\section{Partnerships with Professional Organizations}

PtD staff members continue to reach out to health and safety professionals. Collaboration with the American Industrial Hygiene Association (AIHA) on the PtD initiative involved including references to PtD in the publication of the AIHA Value Strategy report. Sharing information on the need for PtD went beyond this publication to include the offering of professional development courses in conjunction with AIHA conferences, local chapters, and special events. In 2009, as one of the developers and instructors of a professional development course (PDC) at the American Industrial Hygiene Conference and Exposition (AIHce), the PtD program coordinator used case examples to demonstrate the value of PtD concepts. As a result of the popularity of this course, a variety of other PDCs were developed to promote PtD Environmental, Health, and Safety (EHS) interventions and present financial and non-financial benefits from PtD programs. The AIHA 2013 PDC focused on the Value Strategy was very well attended and participants provided valuable feedback concerning PtD. The participants suggested that there is a need for development of a simple tool that incorporates PtD concepts, risk assessment, and financial and non-financial benefits of EHS interventions.

The NIOSH partnership with ABET is growing. A PtD staff member distributed copies of the draft education modules to Program Evaluators (many of whom work in industry) attending the ABET Spring Symposium in 2012 and 2013. Steps are being taken to involve PtD staff in the accreditation of undergraduate engineering programs. $\mathrm{PtD}$ has been the topic at more than 60 professional development courses, webinars, roundtable presentations, and other speaking engagements since 2008.

\section{Practice}

\section{Strategic Goal}

Stakeholders access, share, and apply successful PtD practices.

Practice focuses on identifying and sharing successful procedures, processes, equipment, and tools through on-line databases and other media. Practice also includes demonstrating the value of including workers' health and safety in design decisions and exploring links with the movement towards sustainability. The effort required to implement the successful practice of PtD should not be underestimated. Actions needed to promote the practice of PtD include: Developing business cases 
that are compelling to business leaders; accurately assessing risks inherent to various designs, processes, or procedures; and designing successful tools and equipment (e.g., fall protection systems or machine guarding). A web-based system that utilizes standardized evaluation criteria to share successful PtD processes, procedures, tools, and equipment would be an effective means of disseminating $\mathrm{PtD}$ best practices. Identifying tools and equipment that include safety and health design elements imparts valuable guidance not only to businesses, but also to consumers. Workers play a key role in the success of the current initiative. Their input on the creation of safe work spaces and procedures, tools, and tasks are critical to shaping successful design systems. Identifying successful programs that include worker input in the design process should play a central role in the PtD agenda.

Given current economic realities, it is essential to demonstrate the value of PtD in lean manufacturing to ensure that the implementation of lean does not result in the elimination of programs essential to worker health and safety. By applying PtD methods, companies not only reduce the potential for worker injuries and illnesses (and mitigate the costs associated with them) but also increase their profits through improved work processes and work organization. Developing and disseminating case studies that showcase how companies have improved profits through PtD methods will provide valuable guidance to other businesses.

\section{Practice Outcomes}

\section{Publications and Information Dissemination}

The number of PtD peer-reviewed journal articles has increased significantly. As of May 1, 2013, there were 93 peer-reviewed journal articles cited over 720 times in the peer-reviewed scientific literature. Articles were considered to be on "PtD" topics if the authors used the phrase "Prevention through Design" or the acronym "PtD" in the title, keyword, abstract, or body. Both Professional Safety and the Journal of Safety Research published issues dedicated to PtD (Figure 8). The reach of the PtD concept has extended beyond the PtD Council. Authors are from dozens of countries, including Singapore, Australia, the United Kingdom, China, and the United States. The European Agency for Safety and Health at Work, identified prevention through design in the Priorities for Occupational Safety and Health Research in Europe 2013-2020 [European Agency for Safety and Health 2013].
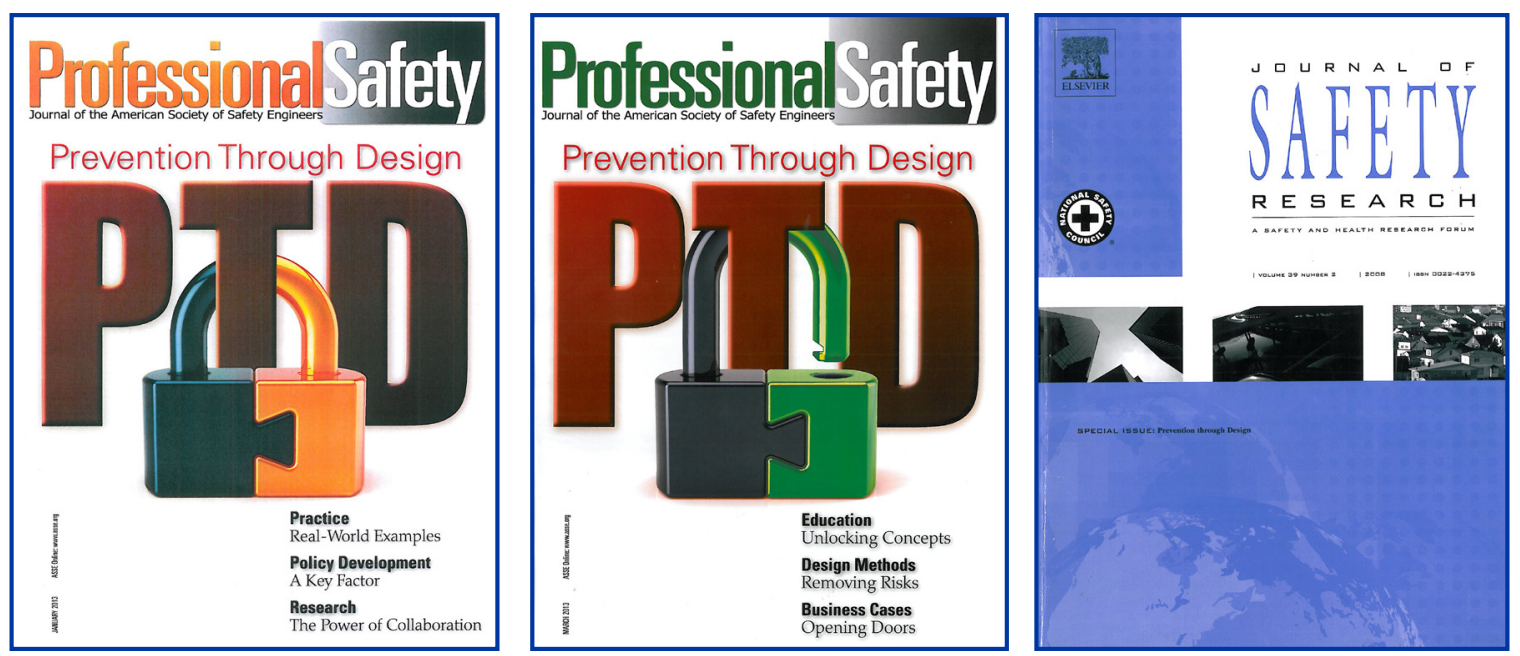

Figure 8. Covers of journals with issues dedicated to PtD. 


\section{Practice wiki}

A PtD wiki (www.orchse.com) is being developed to disseminate PtD concepts by engaging stakeholders in a neutral forum for sharing successful PtD practices. Fourteen case studies have been posted and there are opportunities to create many more. Interested parties can submit ideas to PtD@cdc.gov. When the wiki becomes available for blog-type interaction with the public, it will provide a forum for industry and workers to share best practices and resolve design-related problems. A list of completed case studies is provided in Table 4.

\section{Outreach to Industry}

The PtD program continues to collaborate with industry to identify cost effective Best Practices associated with the adoption of PtD. During fall 2012, PtD staff and Frank Renshaw of Bayberry Consulting, LLC met with the Executive Director of the Construction Users Roundtable (CURT ${ }^{\varpi}$ ) to discuss opportunities for collaboration. Links to the PtD Web and publications were shared with the editor of the CURT publication, The Voice. It is of value to industry to have case studies that communicate the positive return on investment associated with implementation of PtD concepts.

\section{Table 4. Case Studies posted on the PtD Wiki}

\section{Blast Chamber for Spontaneous Explosion of Pyrophoric Gases}

Concrete Imbeds for Guardrail Support

Concrete Straps for Fall Arrest

Double-walled Gas Tubing

Dumbwaiter System for Chemical Transport

Emergency Drop-down Exhaust

Increased Height of Roof Parapets

Loading Docks and Material Staging

Over-pack Containers

Placing Electrical Wiring in Slabs and Underground

Safety in Chemical Handling

Safety in Water System Valve Vault Design

Slippery Surfaces

Soil Retention with Railing 
An effort is under way to bring equipment designers together with purchasers to define the parameters for specific material-handling equipment. Manual material handling ( $\mathrm{MMH})$ is a task common to most sectors, particularly wholesale and retail trade, transportation, utility, and service sectors. MMH can lead to musculoskeletal disorders (MSDs), which cause great pain for workers and are very expensive for employers. One way to address MMH and to prevent MSDs is to design equipment for mechanical handling of materials and to have employers purchase that equipment. Two workshops were held in 2012 and 2013 to bring material handling equipment designers together with purchasers.

One success story is the Construction Industry Institute Research Report (RR101-11) "Addressing Construction Worker Safety in the Project Design". The research effort identified and developed over 400 design suggestions that are available and free to members of the Construction Industry Roundtable. The accumulated suggestions reflect all types of design disciplines, jobsite hazards, and construction components and systems. A computer program, titled "Design for Construction Safety ToolBox," was developed which incorporates the design suggestions accumulated. The program alerts the user to project-specific construction safety hazards and provides suggestions to eliminate or reduce those hazards during the design phase. These are accessible (for free to members of the Construction Industry Institute) at www.construction-institute.org/scriptcontent/more/rr101_11_more.cfm.

Another success story is the Buy-Quiet and Quiet-by-Design programs for hearing conservation that have demonstrated a strong return on investment. NIOSH created an award program to recognize effective and innovative initiatives, share success stories, and encourage others to follow suit. In partnership with the National Hearing Conservation Association, NIOSH awarded the first Safe-in-Sound Excellence in Hearing Loss Prevention Awards ${ }^{\text {rux }}$ in 2009. The recipient of the 2013 Safe-in-Sound Award for Excellence was the Vulcan Materials Company. Recognized for the implementation of a quality, data-driven hearing loss prevention program, Vulcan Materials Company has embraced innovative and cost-effective noise measurement and control strategies. NIOSH has also led efforts to promote Buy-Quiet initiatives including the development of a Power Tools Database to make noise data available to tool buyers, users, and manufacturers of powered hand tools.

\section{Business Case Studies}

The National Initiative has involved several efforts to demonstrate the rationale for including workers' health and safety in design decisions. NIOSH derived the business case for three engineering design solutions: Ergonomic Interventions in Wine Grape Production-Reduced Tub Size from 57 to 46 pounds; Wet Cleaning Technology-Substitute for Dry Cleaning Process; and Patient Lifting Program in the Health Care Industry [Biddle 2013]. The PtD solutions were adopted for different reasons. In the first case the wine industry selected the smaller tubs that weighed less when full than what had been in use, not because of any cost savings or reduction in workers' compensation, but because it was more important to maintain its expert workforce. The second case explored the options for professional garment cleaners to switch from perchloroethlyene (dry cleaning) to wet cleaning processes. The companies used the opportunity to focus the business case for switching chemicals by promoting corporate responsibility with "green" technologies. In the final case, the employer required no more information than the decrease in occupational injury or illness and the accompanying workers' compensation costs.

Current research efforts are moving forward to meet the research and practice goals through development of a user-friendly tool to evaluate the business value of PtD design alternatives. Specifically, the anticipated tool provides a method to develop business cases that are compelling to business leaders. This tool incorporates all steps of the AIHA Value Strategy-one of the most widely used methods to 
derive the Business Case. The PtD Business Case tool integrates all steps in the process, such as the ability to be incorporated into safety and health management systems, and the ability to readily identify the hierarchy of control level for the intervention being examined. The tool identifies and captures cost information for those variables (intervention and impact costs) necessary to calculate financial measures used in business decision-making. It is user-friendly, is inexpensive to operate, and does not require prior knowledge of financial or economic analysis. It also captures information necessary to calculate the non-financial impact of occupational safety and health interventions. The embedded cost calculator derives the financial metrics, including but not limited to Net Present Value, Internal Rate of Return, Return on Investment, and Payback Period. It also derives the non-financial results, such as percent changes in production output, changes in measures of employee satisfaction, and movement toward meeting business objectives.

\section{Impact on Corporate Culture}

Incorporating PtD concepts into the corporate safety culture begins with a policy statement to indicate management support [Renshaw 2012, Renshaw 2013] (Figure 9). As shown in Figure 9, policy forms the justification for company standards. Work processes and procedures are designed and developed and from these flow tools and practices. Various organizations now practice PtD regularly by front loading best practices and lessons learned into the design and redesign process during the Conceptual Design stage.

$\mathrm{NIOSH}$ is developing a topic page to describe each stage of the engineering design process and to identify actions that facilitate the incorporation of PtD concepts. Tools, checklists, and commissioning tests for each stage will be linked to the Web site as they become available. Additionally, a PtD training module that link safety and health practices to the capital project design process and business sustainability is being developed. The PtD staff continues to encourage industry to work collaboratively with NIOSH to identify common occupational hazards and to design strategies for eliminating them.

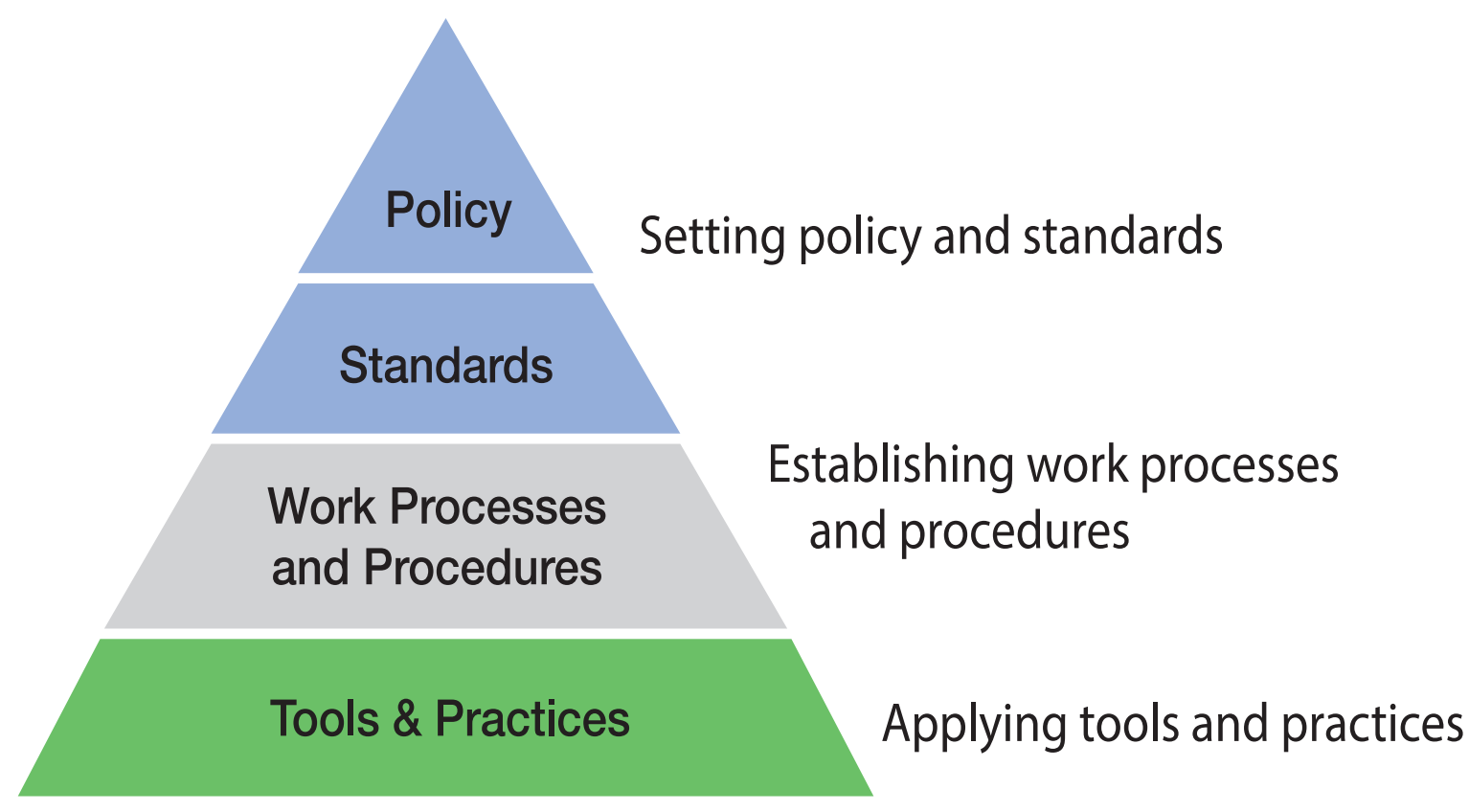

Figure 9. Incorporating PtD methods into the design and redesign process [Renshaw 2012, 2013]. 


\section{Nanotechnology}

A concerted effort is being made to insert PtD into discussions of sustainability, occupational safety and health, and green chemistry [Schulte et al. 2013]. Of particular interest is the effort $\mathrm{NIOSH}$ is making to identify hazards associated with the manufacturing and use of nanomaterials. The NIOSH PtD program and the NIOSH Nanotechnology Research Center (NTRC) collaborated with the State University New York at Albany, College of Nanoscale Science \& Engineering to hold the "Safe Nano Design" workshop in August 2012, http://www.sunycnse.com/Outreach/ NIOSHPresentations.aspx. The purpose was to develop guidance for safe commercialization of nanotechnology products, resulting in guidelines for the safe synthesis of nanoparticles and associated products by means of a PtD approach. The conference illustrated application of $\mathrm{PtD}$ principles at the molecular level as well as during the process phase. Nanomaterials can be designed to mitigate toxicity while maintaining functionality. At the process level various approaches can be designed in to protect workers from exposure to hazardous chemicals, including nanomaterials. Integrating the design efforts at the molecular and process levels may have an even greater impact on worker safety and health. The workshop outcomes include journal papers, collaboration and creation of a guidance document (Figure 10).

\section{Occupational Exposure Banding}

Critical in preventing chemical exposures is the use of occupational exposure limits (OELs) as benchmark for controls and targets for engineering control design. NIOSH is currently developing a systematic health hazard banding approach to assist safety and health professionals in providing guidance for chemicals without authoritative OELs, thus facilitating the application of PtD to mitigate hazards and minimize risks to chemical agents. The NIOSH health hazard banding process can be used with limited information and resources and can be performed quickly by in-house industrial hygienists and health and safety specialists. The outcome of the health hazard banding process is an occupational exposure band (OEB). The bands group together chemicals without authoritative OELs on the basis of toxicology and potency.

The value of occupational exposure banding is apparent in light of the number of chemicals that lack authoritative OELs. According to the Environmental Protection Agency (EPA), the Toxic Substances Control Act (TSCA) Chemical Substance Inventory contains more than 84,000 chemicals. OELs have been developed for only a small subset of these chemicals. Therefore, for most chemicals there are no authoritative recommendations on a target exposure level to which exposures should be controlled. Occupational exposure banding can be used to supplement and support OEL development by facilitating more rapid evaluation of health risks, providing guidance for chemicals without OELs, and identifying hazards to be evaluated for elimination or substitution. The method also can provide recommendations when minimal data are available and provide a tool for the development of NIOSH Recommended Exposure Limits (RELs).

In November 2011, NIOSH hosted a two-day meeting with stakeholders to gain input on the occupational exposure banding process used by industry. The Education breakout session identified strategies to train workers in the understanding and use of control banding [NIOSH 2009]. The Development session debated various approaches to separate chemicals into bands. As the project progressed, NIOSH conducted an inventory of hazard codes for health criteria for emergency responders and the occupation health community. The primary objective was to create a readily understandable coding system that would not cause confusion during emergencies. During the next two years, NIOSH staff made several presentations at national meetings and local AIHA section meetings to promote 


\section{Molecule to Manufacturing to Market}

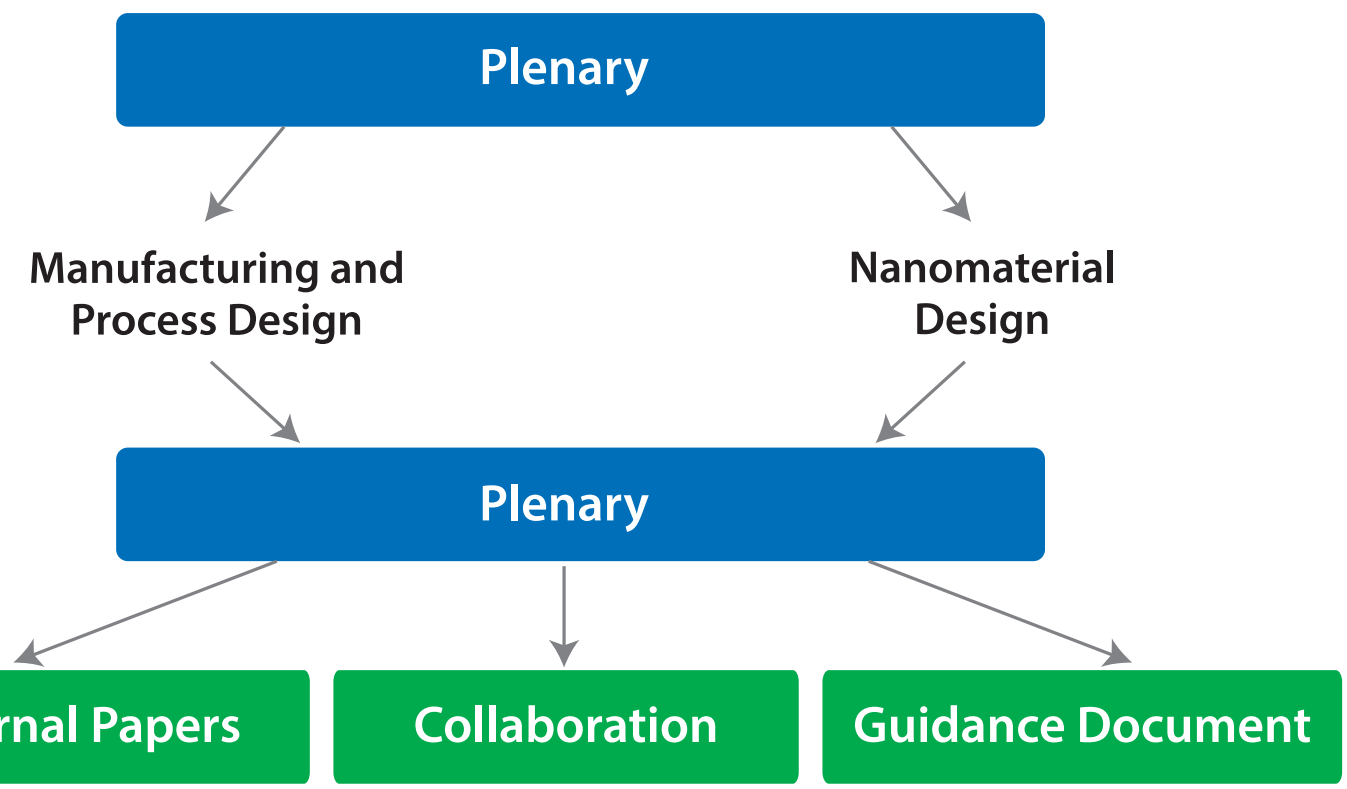

Figure 10. 2012 Safe Nano Design Workshop.

occupational exposure banding concepts to the occupational safety and health community. Throughout, NIOSH has communicated with AIHA, ACGIH and other key stakeholders to build support for this tool for the profession. NIOSH plans to publish a draft occupational exposure banding decision logic document for public comment and peer review. Publication of the final decision logic including case studies to illustrate the occupational exposure banding process is anticipated.

\section{Policy}

\section{Strategic Goal}

Business leaders, labor, academics, government entities, and standard-developing and setting organizations endorse a culture that includes PtD principles in all designs affecting workers.

Policy focuses on creating demand for safe designs for workers and incorporating these safety and health considerations into guidance, regulations, recommendations, operating procedures, and standards. The basis for building a culture of safety is the development of a broad, overarching policy to serve as a roadmap for establishing PtD processes and programs for enterprises of all sizes, across all industrial sectors. The integration of PtD concepts in consensus standards creation provides outcome-based guidance. Relevant recommendations from various authoritative and advisory organizations should reflect PtD principles. The ultimate goal is to include PtD principles in all design standards that affect workers. 


\section{Policy Outcomes}

\section{Consensus Standards}

PtD concepts have been added to at least 25 consensus standards since the initiative began, as shown in Table 5. In 2009, the ASSE Board of Directors recommended the development of a stand-alone standard to encourage the elimination of workplace hazards through design, in support of the PtD initiative. The basis for the new standard was ASSE TR-Z790.001-2009.

In 2011, the ASSE obtained approval from the American National Standards Institute (ANSI) for ANSI/ASSE standard Z590.3, "Prevention through Design: Guidelines for Addressing Occupational Risks in Design and Redesign Processes" (Figure 11). This standard provides guidance on including PtD concepts within an occupational safety and health management system, and can

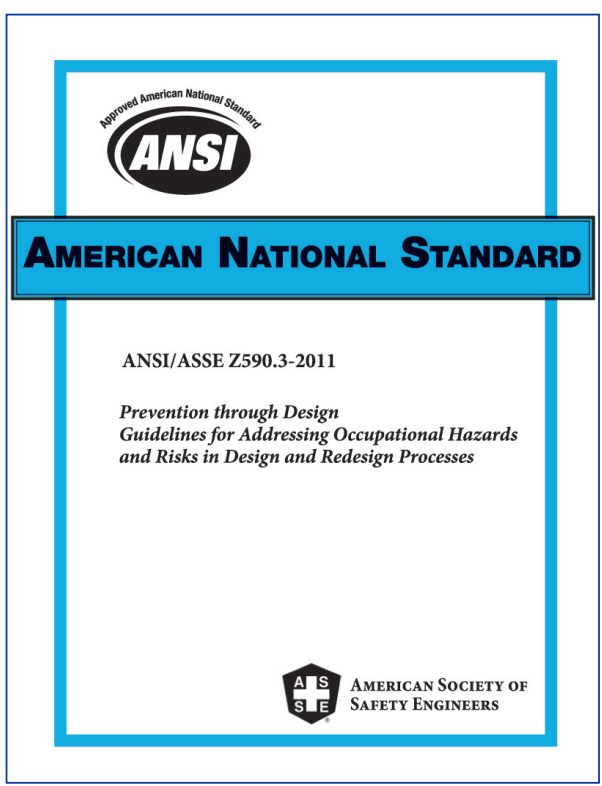

Figure 11. The ANSI/ASSE standard Z590.3 document cover be applied in any occupational setting. The standard focuses specifically on the avoidance, elimination, reduction, and control of occupational safety and health hazards and risks in the design process. PtD concepts have also been incorporated in the 2013 revision of the ANSI/AIHA/ASSE joint standard Z-10 Occupational Health and Safety Management Systems Standard.

According to Z10, the process for design and redesign and management of change shall include:

A. Identification of tasks and related health and safety hazards;

B. Recognition of hazards associated with human factors, including human errors caused by design deficiencies;

C. Review of applicable regulations, codes, standards, internal and external recognized guidelines;

D. Application of control measures (hierarchy of controls);

E. Determination of appropriate scope and degree of the design review and management of change; and

F. Employee participation [ANSI 2012].

\section{Small Business}

\section{Strategic Goal}

Small businesses have access to PtD resources that are designed for or adapted to the small business environment.

For small businesses, the goal is to explore methods for tailoring and diffusing successful PtD practices and programs to them. Small businesses often lack in-house capacity to address PtD issues. Thus, the National Initiative calls for adapting successful PtD practices and programs to the small business 


\section{Table 5. Consensus Standards including PtD Concepts}

AlHA-ANSI Z-10, Occupational Health and Safety Management Systems

ANSI A10, Safety in Construction and Demolition Operations

ANSI B11.0.2010, Safety Standards for Machine Tools

ANSI B11.19.2010, Performance Requirements for Safe Guarding

ANSI Z244.1, Control of Hazardous Energy

ANSI Z87, Safety Standards for Eye Protection

ANSI/AIHA Z9, Health and Safety Standards for Ventilation Systems

ANSI/ISO 12100:2010, Safety of Machinery: General Principles for Design-Risk Assessment and Risk Reduction

ANSI/PMMI B155.1, Safety Requirements for Packaging Machinery and Packaging-Related Converting Machinery

ASHRAE 161, Air Quality within Commercial Aircraft

ASHRAE 5.08, Industrial Ventilation

ASHRAE 9.06, Healthcare Facilities

ASHRAE 9.11, Clean Spaces

ASSE PtD Technical Report TR-Z790.001-2009

ASSE-ANSI PtD Standard Z590.3.2011, Prevention through Design: Guidelines for Addressing Occupational Risks in Design and Redesign Processes

ISA 12, Electrical Equipment for Hazardous Locations

MIL-STD-882E, Department Of Defense Standard Practice: System Safety

NFPA 70E, Standard for Electricity in the Workplace

NFPA 79, Industrial Machinery Electrical Requirements

SAE J2194, Roll -Over Protective Structures for Wheeled Agricultural Tractors

SEMI S14, Safety Guidelines for Fire Risk Assessment and Mitigation for Semiconductor Manufacturing Equipment

SEMI S2, Environmental, Health, and Safety Guideline for Semiconductor Manufacturing Equipment

UL 2201, Portable Engine-Generator Assemblies

ISO 31000, Risk Management

ISO 14798, Lifts (elevators), escalators and moving walks-Risk assessment and reduction methodology 
environment. Case studies highlighting successful practices, programs and interventions at the small business level demonstrate cost effective design solutions for these establishments.

\section{Small Business Outcomes}

NIOSH has facilitated the adoption of safe work practices in small business environments. One initiative includes an outreach to intermediaries such as chambers of commerce, trade associations, suppliers, and insurance companies as an avenue to reach out to small businesses with the information on how adding safety and health programs can add value to their business [Sinclair et al. 2013].

Another small business outreach is through the ORCHSE Strategies, LLC (formerly Mercer, ORC Worldwide ${ }^{\mathrm{TM}}$ ) sponsorship of an Environment, Health and Safety Center of Excellence to serve as an online repository where research results and best practice information are made publicly available. This repository of "solutions for specific trades and tasks" is built on a wiki platform, is intended to foster collaboration among all employers, safety and health professionals, academicians, government, labor, and workers as a place where anyone can contribute. It has value for small businesses who want to "do the right thing" but may lack knowledge or resources for implementing safety and health concerns.

An additional small business outreach is being accomplished by the NIOSH nanotechnology research center. NIOSH has been conducting exposure assessments at nanomaterial production and user facilities to support epidemiologic and control research, and the development of comprehensive risk management guidance. Since 2006, NIOSH researchers have conducted over 40 workplace investigations at research facilities, pilot plants, and manufacturing sites that are actively making or using engineered nanomaterials. This research effort has been one of the most productive activities because of the success of engaging the private sector as partners. From these efforts, NIOSH has developed partnerships with large and small nanomaterial manufacturing companies and has gained invaluable insight on how nanomaterials are being handled. At the 2010 Nanomanufacturing Summit, sponsored by the NanoBusiness Commercialization Association, four companies publically described their experience with NTRC researchers as being extremely helpful in providing guidance on the safe handling of engineered nanomaterials. One of those companies, NanoComp Technologies, Inc., listed NIOSH as a key partner in developing an effective EHS program that supported the growth of its company [Banash 2010].

\section{Research to Practice}

The NIOSH Research to Practice (r2p) program was designed to facilitate the transfer of technology and information from the public sector to the private sector. A small business often lacks access to capital to develop effective solutions to eliminate hazards. The r2p program allows NIOSH and small businesses to evaluate design alternatives in real world applications. This iterative process may result in a patentable product.

Many applications of PtD are applicable for small businesses. Adoption of products where hazards have been designed out can benefit companies of all sizes. In partnership with the National Asphalt Pavement Association/Asphalt Pavement Alliance, NIOSH-supported research into warm mix asphalt showed reduced worker exposure to volatile organic compounds (VOC) [Acott 2011]. NIOSH also worked with wineries to design and evaluate a smaller grape harvesting tub to reduce musculoskeletal injuries [Wolfe 2012]. On commercial fishing vessels, the incidence of entanglement and subsequent 
injuries and death was reduced by the design of an emergency stop on capstan winches [Lincoln et al. 2008]. The adoption of a comprehensive patient lifting policy that required lifting-assistive devices resulted in a substantial cost savings [Biddle 2013 ]. Coating the chain on a coal conveyor belt reduced noise significantly and extended the life of the chain [Kovalchik et al. 2008]. In depth descriptions of these PtD applications can be found in the PtD in Motion newsletters http://www.cdc.gov/niosh/ topics/ptd/ and at http://www.asse.org/professionalaffairs_new/ptd.php.

\section{Future Objectives}

The seventh year of the initiative will be marked in 2014. Reviewing the work still to be accomplished and considering the interest of stakeholders, NIOSH intends to continue the initiative for another five-year period (2015-2020). The focus will be to solidify the gains made thus far, address unmet objectives in the current strategic plan, and respond to new stakeholder needs.

The focus of the next five years will be to meet needs identified in this report and the strategic plan, and ultimately continue efforts to achieve a change in culture so that designing out hazards for workers becomes the normal practice. NIOSH intends to obtain new stakeholder input on the future of the initiative and requests that comments, suggestions, and recommendations be sent to PtD@cdc.gov. A series of public workshops will also be coordinated to obtain stakeholder input.

Critical to making progress in institutionalizing PtD is to continue to influence educational systems through demands from industry and employees. NIOSH will assess the output of educational systems in terms of trained engineers, architects, designers, and purchasers. Additionally, the practice of occupational safety and health needs to include PtD principles in OSH risk management systems. Until $\mathrm{PtD}$ is central to risk management, efforts to prevent occupational illness, injury, and death will be impaired and the cost of not implementing PtD will be significant. The progress made to date is a good foundation, but more progress is needed to ensure worker protection. 


\section{PtD Contributors and Participants}

The authors thank the following for contributing to and participating in the initiative:

\begin{tabular}{|c|c|c|c|c|c|}
\hline D. Abelson & T. Bohn & G-X. Chen & F. Dougherty & E. Foulke & D. Hartley \\
\hline A. Abrams & J. Boiano & W-C. Chen & M. Douglas & J. Fradella & C. Hartz \\
\hline M. Acott & U. Bollmann & M. Childress & R. Dressler & C. Franklin & R. Harvey \\
\hline P. Adams & R. Bonner & M. Chmelar & D. Drollinger & J. Frederick & W. Haskell \\
\hline S. Afanuh & L. Boord & T. Christensen & R. Duffy & J. Frederiksen & D. Haumann \\
\hline D. Alexander & J. Borowski & W. Christensen & C. Duncan & J. Froetscher & C. Hayden \\
\hline D. Alhaique & C. Bowman & M. Clark & J. Duncan & K. Fujishiro & F. Hayes \\
\hline D. Allen & W. Boyd & S. Clark & S. Durdin & P. Furst & L. Haython \\
\hline J. Allen & J. Bradley & P. Clegg & K. Durst & M. Galvin & T. Headley \\
\hline K. Alston & C. Branche & L. Climenhaga & G. Earle- & C. Galligan & F. Hearl \\
\hline S. Al-Tuwaijri & B. Brandt & K. Cline & Richardson & J. Gambatese & P. Heckel \\
\hline H. Amandus & T. Braun & C. Clinton & S. Earnest & P. Garapati & S. Hecker \\
\hline V. Anderson & S. Brenner & S. Cloutier & A. Ebner & J. Garland & M. Hedgson \\
\hline R. Andres & J. Breskey & C. Coe & A. Edens & C. Garner & D. Heidel \\
\hline J. Annis & R. Briers & S. Cole & M. Edens & J. Garrington & M. Heembrock \\
\hline I. Antauer & H. Brightman & D. Colin & S. Edwards & C. Garvey & D. Heidorn \\
\hline D. Asifamabia & I. Brilakis & J. Collins & W. Eggleston & S. Gauthier & M. Henderek \\
\hline M. Ayub & J. Brinkmeyer & N. Comeau & D. Eherts & M. Geiger & J. Henshaw \\
\hline J. Bader & S. Bristow & J. Conery & G. Eijkemans & K. Glenn & J. Hernandez Flores \\
\hline C. Baier-Anderson & R. Bronkhorst & N. Connell & B. Eisenman & C. Geraci & R. Herrick \\
\hline K. Balakrishnan & D. Brown & C. Constatinou & D. Elisburg & K. Gerwig & D. Hicks \\
\hline R. Baldwin & E. Brown & T. Cooke & G. Elkin & J. Getty & M. Hillyer \\
\hline J. Banaag & K. Brownstein & B. Cooper & M. Ellenbecker & A. Gibb & J. Hingston \\
\hline D. Bang & W. Brumfield & D. Cooper & D. Ellenberger & B. Giles & D. Hinze \\
\hline J. Barab & S. Buchanan & C. Costas & M. Ellis & E. Gill & L. Hix \\
\hline B. Barber & L. Buff & L. Couillard & N. Ellis & M. Gillen & A. Ho \\
\hline B. Bare & M. Buono & L. Crane & D. Engdahl & R. Gillespie & L. Hodson \\
\hline J. Barnes & G. Burdge & W. Creaser & J. Erdman & K. Goedel & A. Hogan \\
\hline M. Barrett & C. Burgio & S. Cronin & A. Ertas & G. Goodman & B. Holton \\
\hline M. Barsan & S. Burkhammer & A. Currant & E. Esswein & N. Gordon & M. Hoover \\
\hline J. Bartley & J. Burkhardt & M. Cushmac & C. Estill & R. Gosnell & J. Hopkins \\
\hline R. Beach & A. Burno & S. Cusson & J. Etherton & P. Gottesfeld & R. Hopper \\
\hline S. Bealka & D. Burns & E. Dacey & P. Evans & D. Gottesman & D. Hornback \\
\hline J. Beaupre & L. Byrd & L. Dalsey & K. Faber & P. Gough & M. Hornych \\
\hline M. Behm & L. Byrnes & B. Dames & R. Fairfax & J. Gray & M. Hornychova \\
\hline T. Bellingar & D. Caldwell & R. D'Andrea & E. Faria & J. Green & W. Horsford \\
\hline D. Bender & R. Call & Q. Danezza & G. Fazio & M. Gressel & J. Howard \\
\hline A. Bennett & R. Callor & A. Dannenberg & S. Fees & M. Grete & J. Howe \\
\hline J. Bennett & G. Calvert & C. Davis & C. Feigley & D. Grigg & J. Huang \\
\hline M. Bennier & A. Cammarota & D. Davis & I. Feitshans & J. Grosch & S. Hudock \\
\hline K. Berg & G. Camomilli & H. Davis & D. Felinski & M. Guevara & D. Hudson \\
\hline D. Bergstrom & J. Campbell & J. A. Decker & S. Fendinger & S. Gunn & C. Hughes \\
\hline J. Berman & K. Campbell-Miles & M. Dehghani & A. Fendley & L. Gustafsson & N. Hughes \\
\hline A. Berry & S. Campleman & K. DeMeester & E. Fidler & K. György & S. Hughes \\
\hline D. Bersano & J. Cantin & J. DeMesme-Gray & A. Filko & C. Haas & D. Hull \\
\hline E. Biddle & L. Carey & S. Derman & G. Finfinger & G. Hagan & B. Husberg \\
\hline D. Biderman & J. Carter & L. DiBerardinis & M. Fingerhut & J. Haight & J. Huy \\
\hline M. Bidez & A. Casaru & A. Diego & J. Fisher & D. Hales & W. Imbrechts \\
\hline E. Bintner & M. Casla-Benito & I. Dobrushin & E. Frumin & A. Hall & B. Jacklitsch \\
\hline L-M. Bjurstrom & T. Cecich & J. Dolan & K. Flannery & R. Hall & D. Jacobs \\
\hline M. Blada & M. Cervarich & J. Donaldson & K. Flechler & M. Hallowell & G. Jameson \\
\hline F. Blosser & M. Chambers & J. Donaldson & L. Floyd & E. Harbin & C. Järnstedt \\
\hline D. Bloswick & C-C. Chang & M. Dorsch & M. Foley & A. Harney & M. Jarry \\
\hline T. Bock & L. Chapman & G. Dotson & G. Fore & J. Harris & L. Jenkins \\
\hline D. Boettner & P. Check & D. Dougherty & C. Forrester & A. Harte & D. Jepson \\
\hline
\end{tabular}




\section{PtD Contributors and Participants (continued)}

The authors thank the following for contributing to and participating in the initiative:

\begin{tabular}{|c|c|c|c|c|c|}
\hline L. Jillings & R. Davis Layne & L. McKernan & A. Peters & P. Serrano & C. Voellmicke \\
\hline J. Jimenez & J. Leary & A. McKinley & S. Peters & R. Sesek & P. Vossenas \\
\hline C. Jobson & T. Lentz & K. McPhaul & T. Petricek & T. Shanahan & L. Wade \\
\hline J. Johnson & W. Leavitt & G. McPhee & J. Piacentino & R. Shea & G. Wagner \\
\hline R. Johnson & L. Jackson Lee & B. Meade & F. Pilotti & J. Sheehy & H. Wahl \\
\hline C. Jones & C. Legan & P. Meckl & M. Plagge & T. Sheridan & B. Walsh \\
\hline W. Jones & D. LeGrande & G. Menon & J. Platner & R. Shinn & M. Watters \\
\hline B. Joseph & M. Lemoine & P. Merfeld & G. Popov & D. Shipp & T. Weakley \\
\hline S. Jurss & N. Lessin & D. Michaels & D. Porter & G. Shor & J. Weaver \\
\hline S. Kaczmarek & P. Levy & P. Middendorf & R. Potts & T. Siegrist & D. Wegman \\
\hline K. Kalaijian & M-L. Lin & P. Moore & T. Pouchot & B. Silkowski & D. Weil \\
\hline S. Kalimullah & J. Linhard & S. Mooser & R. Powers & A. Silva & M. Weinstein \\
\hline S. Kanth & M. Lioce-Mata & T. Morgan & J. Poythress & R. Simmons & D. Weinstock \\
\hline R. Karia & B. Lippy & B. Morris & S. Pratt & M. Sjoberg & D. Weissman \\
\hline T. Katz & J. Lipscomb & G. Mosier & G. Pugliese & B. Sjoholm & M. Weil \\
\hline P. Kavalchic & B. Little & J. Mroszczyk & A. Pustelnik & A. Smith & J. Welter \\
\hline T. Kawakami & J. Lloyd & V. Murashov & D. Quintero & S. Soderholm & A. West \\
\hline L. Kayman & A. Longmate & C. Myers & M. Quinn & A. Soon & F. White \\
\hline D. Keenan & L. Lopes & M. Myers & S. Rajendran & A. Speegle & J. White \\
\hline S. Keffer & G. Lotz & J. Neil & J. Randolph & M. Spencer & M.White \\
\hline C. Kendrick & D. Ludwin & S. Newell & E. Rauser & C. Springs & R. Whitehead \\
\hline B. Kenny & M. Lum & L. Nguyen & L. Reed & G. Staffo & V. Williams \\
\hline L. Kenny & T. Ly & R. Niemeier & T. Regenza & J. Steger & M. Willis \\
\hline M. Kent & T. Lyons & G. Niewiadomski & R. Reger & K. Stephenson & M. Wilson \\
\hline M. Keyserling & S. Machida & F. Norton & T. Rehak & E. Stewart & J. Windau \\
\hline M. Kiefer & D. MacLeod & S. Nosdall & F. Renshaw & G. Stoev & E. Winer \\
\hline S. Kiesling & K. MacMahon & J. Nunes & F. Rice & G. Stone & D. Wirges \\
\hline K. Kimbro & S. Madar & T. Nupponen & R. Rinehart & E. Storey & S. Witek-Eames \\
\hline B. King & G. Maggio & C. O’Connor & K. Ringen & D. Strauss & A. Wolak \\
\hline P. King & B. Main & C. O’Dell & K. Rodenburg & C. Stribling & A. Wolfe \\
\hline S. King & C. Malcolm & D. O’Konski & J. Roemer & V. Sublet & D. Woodhull \\
\hline K. Kirkland & C. Maloney & M. Ocy & R. Rosa & M. Suits & M. Wright \\
\hline M. Kitt & A. Mann & A. Oelsner & B. Rosenberg & R. Svehla & D. Youhas \\
\hline P. Knox & F. Manuele & A. Okun & K. Ross & N. Swanson & J. Young \\
\hline J. Kohler & T. Mapes & M. Omar & C. Roth & S. Swanson & D. Young-Corbett \\
\hline I. Kokalov & D. Marciniak & G. Orr & R. Rummer & M. Sweeney & T. Zarges \\
\hline B. Koning & P. Markkanen & T. Osborne & E. Russell & D. Synder & M. Zisner \\
\hline T. Kozminski & P. Marmion & S. Outin & V. Russell & R. Taber & R. Zumwalde \\
\hline T. Kramer & M. Marshall & R. Paige & A. Ruttenberg & J. Takala & \\
\hline T. Krietz & K. Marthe & R. Pana-Cryan & H. Saiyed & M. Taubitz & \\
\hline U. Kristjuhan & M. Marvi & M. Pankonin & W. Salter & J. Teizer & \\
\hline R. Krzywicki & A. Mashayekhi & E. Papp & J. Sampson & E. Thimons & \\
\hline $\mathrm{K} . \mathrm{Ku}$ & J. Mason & D. Parker & M. Sanders & T. Thomas & \\
\hline D. Kubickova & M. Massoni & T. Pasteris & L. Sanderson & S. Thompson & \\
\hline R. Kulick & K. Masterson & D. Paul & L. Sayre & J. Tickner & \\
\hline E. Kwon & R. Matetic & H. Payne & K. Schaefer & T. Toole & \\
\hline S. Laddychuck & D. Mattos & M. Pearson & A. Schill & J. Topmiller & \\
\hline A. Lamba & R. Matuga & T. Pechar & S. Schneider & C. Trahan & \\
\hline T. LaMontagne & M. Mavely & C. Peedin & M. Seymour & T. Uahinui & \\
\hline P. Landsbergis & W. Maynard & J. Pelletier & T. Schnorr & D. Utterback & \\
\hline M. Lane & D. McCausland & R. Pentecost & P. Schulte & J. Van Houten & \\
\hline M. Latko & T. McCleary & A. Pereira & M. Schwarzman & R. Van Steenbergen & \\
\hline S. Lavender & G. McCluskey & R. Perimaki & J. Scott-Blanton & M. Vanmierlo & \\
\hline D. Lavoie & J. McGlothlin & K. Perritt & P. Seeley & R. Verma & \\
\hline M-C. Lavoie & D. McKenzie & B. Perry & G. Seitz & A. Vidakovic & \\
\hline
\end{tabular}




\section{References}

Acott M [2011]. Catching lightning in a bottle. Plenary session at Prevention through Design-a new way of doing business: a report on the National Initiative, 2011 Washington, DC. August 22-24. http://www.asse.org/professionalaffairs_new/ptd.php

ANSI/AIHA/ASSE Z10-2012 [2012]. American National Standard for Occupational Health \& Safety Management Systems. American Society of Safety Engineers, Des Plaines, IL.

Banash M [2010]. Managing NanoEHS: Moving from the lab to the plant. Northeast Nanomanufacturing Summit. Lowell, MA, June 22-24.

Biddle E [2013]. Business cases: supporting PTD solutions. Professional Saf 2013 Mar; 58(3):56-64.

Biddle E [2011]. Have major US companies adopted prevention through design (PtD) practices and policies? Presented at the National Occupational Injury Symposium, Morgantown, WV, October 18-20.

Driscoll TR, Harrison JE, Bradley C, Newson RS [2008]. The role of design issues in work-related fatal injury in Australia. J Safety Res 39(2):209-214.

European Agency for Safety and Health at Work [2013]. Priorities for occupational safety and health research in Europe 2013-2020. Luxembourg: Publications Office of the European Union. ISBN: 97892-9240-068-2

Gambatese JA [2013]. Final Report-Activity 2: Assess the effects of PtD regulations on construction companies in the UK. Submitted to the National Institute for Occupational Safety and Health (NIOSH).

Gambatese JA, Gibb AG, Bust P, Behm M [2009]. Industry's perspective of design for safety regulations. Working together: planning, designing, and building a healthy and safe construction industry, CIB W99 Conference, Melbourne, Australia, Oct. 21-23.

Health \& Safety Commission [1994]. Construction (Design and Management) Regulations (CDM). SI 1994/3140 HMSO. London: Health \& Safety Commission.

Jeffrey J, Douglas I [1994]. Safety performance of the United Kingdom construction industry. In: Proceedings of the Fifth Annual Rinker International Conference Focusing on Construction Safety and Loss Control, University of Florida, Gainesville, FL, Oct. 12-14, 1994.

Kovalchik P, Matetic R, Smith A, Bealco S [2008]. Application of prevention through design for hearing loss in the mining industry. J Saf Res 39(2):251-254.

Lincoln J, Lucas D, McKibbin R, Woodward C, Bevan, J [2008] Reducing commercial fishing deck hazards with engineering solutions for winch design. J Saf Res 39(2):231-235.

Newell S, Biddle E [2011]. Benchmarking management practices related to PtD in the U.S. Prevention through design - a new way of doing business: report on the national initiative, Washington, DC, August 22-24.

NIOSH [2011]. Prevention through design: plan for the national initiative. Cincinnati, OH: U.S. Department of Health and Human Services, Centers for Disease Control and Prevention, National Institute for Occupational Safety and Health, DHHS (NIOSH) Publication No. 2011-121. www.cdc.gov/ niosh/docs/2011-121/ 
NIOSH [2009]. Qualitative risk characterization and management of occupational hazards: control banding (CB). Cincinnati, OH: U.S. Department of Health and Human Services, Centers for Disease Control and Prevention, National Institute for Occupational Safety and Health, DHHS (NIOSH) Publication No. 2009-152. www.cdc.gov/niosh/docs/2009-152/

Omar M, Quinn M, Buchholz B, Geiser K [2013]. Are green building features safe for preventive maintenance workers? Examining the evidence. Am J Ind Med 56(4):410-23.

Peterson JE [1973]. Principles for controlling the occupational environment. The industrial environment-its evaluation and control. Cincinnati, OH: U.S. Department of Health and Human Services, Centers for Disease Control and Prevention, National Institute for Occupational Safety and Health, DHHS (NIOSH), p 117.

Renshaw FM [2013]. Design: methods for implementing PTD. Prof Safety 58(3):50-55. www.asse.org/ professionalsafety/search/index3.php

Renshaw FM [2012]. Incorporating prevention through design methods into the design and redesign process. American Industrial Hygiene Association 2012 Fall Conference, Miami, FL, September 28October 2.

Schulte P, Rinehart R, Okun A, Geraci C, Heidel D [2008]. National prevention through design (PtD) initiative. J Safety Res 39:115-121. www.cdc.gov/niosh/topics/ptd/pdfs/Schulte.pdf

Schulte P, McKernan L, Heidel D, Okun A, Dotson GS, Lentz T, Geraci C, Heckel P, Brance C [2013]. Occupational safety and health, green chemistry and sustainability: a review of areas of convergence. Environ Health 12(4):31. www.ehjournal.net/content/12/1/31

Sinclair R, Cunningham T, Schulte P [2013]. A model for occupational safety and health intervention diffusion to small businesses. Am J Ind Med 56(12):1442-1451.

Wolfe A [2012]. Improving the lives in wine grape harvesting industry through PtD, at Prevention through Design - a new way of doing business: a report on the National Initiative, 2011, Washington, DC. August 22-24. www.asse.org/professionalaffairs_new/ptd.php 



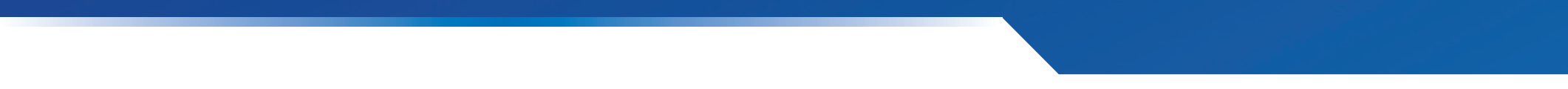




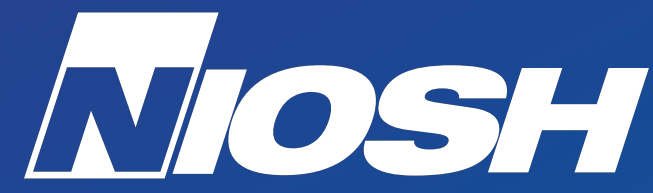

Delivering on the Nation's promise:

Safety and health at work for all people

through research and prevention

To receive $\mathrm{NIOSH}$ documents or more information about occupational safety and health topics, contact $\mathrm{NIOSH}$ :

$$
\text { 1-800-CDC-INFO (1-800-232-4636) }
$$

TTY: 1-888-232-6348

E-mail: cdcinfo@cdc.gov

or visit the NIOSH website at http://www.cdc.gov/niosh.

For a monthly update on news at NIOSH, subscribe to NIOSH eNews by visiting www.cdc.gov/niosh/eNews.

DHHS (NIOSH) Publication No. 2014-123

SAFER • HEALTHIER • PEOPLETM 